Wirtschaftswissenschaftliches Zentrum (WWZ) der Universität Basel

$\mathrm{WW} \mid \mathrm{Z}$

December 2011

\title{
Are Forced Turnovers Good or Bad News?
}

WWZ Discussion Paper 2011/10

(D-136)

Axel Kind, Yves Schläpfer 
The Authors:

\section{Prof. Dr. Axel Kind}

University of Basel

Department of Finance (WWZ)

Peter Merian-Weg 6

CH - 4002 Basel

Telefon: +41(0)61 2673310

axel.kind@unibas.ch

\section{Yves Schläpfer}

University of Basel

Department of Finance (WWZ)

Peter Merian-Weg 6

CH - 4002 Basel

A publication oft the Center of Business and Economics (WWZ), University of Basel.

(c) WWZ Forum 2011 and the author(s). Reproduction for other purposes than the personal use needs the permission of the author(s).

\section{Contact:}

WWZ Forum | Peter Merian-Weg 6 | CH-4002 Basel | forum-wwz@unibas.ch | www.wwz.unibas.ch

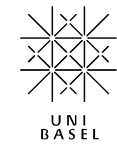




\title{
Are Forced CEO Turnovers Good or Bad News?*
}

\author{
Axel Kind ${ }^{\dagger} \quad$ Yves Schläpfer ${ }^{\ddagger}$
}

May 2011

\begin{abstract}
To gain insights about the quality of board's firing decisions, we investigate abnormal stock returns and operating performance around CEO-turnover announcements in a new handcollected sample of 208 "clean" turnover events between January 1998 and June 2009. Unlike the majority of previous studies, we show that forced turnovers do not per se represent a positive signal to shareholders. On the contrary, investors seem to critically assess the board's firing decision by considering the quality of the departing manager. When an outperforming $\mathrm{CEO}$ is dismissed or forced to leave - an event that occurs in as many as $35 \%$ of all dismissals in our sample - shareholders disesteem the board's decision. This finding is confirmed in multivariate cross-sectional regressions, holds for different time subperiods, and is robust to various event-test specifications and proxies of CEO quality.
\end{abstract}

Keywords: CEO turnover; Corporate governance; Firm performance JEL codes: G14; G30; G34

\footnotetext{
${ }^{*}$ Contact information: Email A. Kind: axel.kind@unibas.ch; Email Y. Schläpfer: yves.schlaepfer@unibas.ch. An earlier version of this paper circulated under the title "Is a CEO Turnover Good or Bad News?". We are grateful for the financial support provided by the WWZ Förderverein under Project D-136. We thank Manuel Ammann, Beat Hintermann, J. Ronald Hoffmeister, Jochen Hundsdoerfer, Jayant R. Kale, Stephan Kessler, Yvan Lengwiler, Frederik Lundtofte, Ernst Maug, Ebru Reis, Ralf Sabiwalsky, Markus Schmid, George Sheldon, Alois Stutzer, Anders Vilhelmsson, Hannes Wagner, Evert Wipplinger, Rico von Wyss, Heinz Zimmermann, and participants at the 2010 Financial Management Association Annual Meeting in Hamburg, the 2010 European Finance Association Annual Meeting in Frankfurt, the 2010 German Finance Association Annual Meeting in Hamburg, the Research Seminars or Workshops of the Freie Universität Berlin, Lund University, University of Basel, and University of St. Gallen (in Flims) for their very helpful comments. A special thank goes to Ann-Kathrin Fritze, Anja Frommherz, and Marco Poltera for their excellent research assistance.

${ }^{\dagger}$ Department of Finance, University of Basel and Swiss Institute of Banking and Finance, University of St. Gallen.

† Department of Finance, University of Basel.
} 


\title{
Are Forced CEO Turnovers Good or Bad News?
}

\begin{abstract}
To gain insights about the quality of board's firing decisions, we investigate abnormal stock returns and operating performance around CEO-turnover announcements in a new handcollected sample of 208 "clean" turnover events between January 1998 and June 2009. Unlike the majority of previous studies, we show that forced turnovers do not per se represent a positive signal to shareholders. On the contrary, investors seem to critically assess the board's firing decision by considering the quality of the departing manager. When an outperforming CEO is dismissed or forced to leave - an event that occurs in as many as $35 \%$ of all dismissals in our sample - shareholders disesteem the board's decision. This finding is confirmed in multivariate cross-sectional regressions, holds for different time subperiods, and is robust to various event-test specifications and proxies of CEO quality.
\end{abstract}

\section{Introduction}

The duty of a Chief Executive Officer is to maximize shareholders' wealth by taking sensible management decisions. Given the scope and importance of this mission, it is evident that a CEO turnover represents a major event in the history of a corporation, with possibly far reaching consequences for the company and its shareholders. Along these lines, Bertrand and Schoar (2003) show that the individual management style of a CEO directly affects the investment and financial policy as well as the organizational strategy and the performance of a company.

The aim of this paper is to assess the impact of (forced) CEO turnovers on shareholder value. Much academic work on company boards is dedicated to the question whether they act as "watchdogs" or "lapdogs". We take a different stance on this debate by asking whether boards acting as watchdogs (i.e. by firing CEOs) do so in a sensible manner: Are they good or bad "watchdogs"? More precisely, by investigating the cross-sectional variation of abnormal stock returns around (forced) CEO turnovers, we study whether boards of directors act in the shareholders' interest.

A real-world example will best illustrate the economic story of this paper. The example refers to Mr. Fred Kindle, former CEO of ABB Ltd, a global leader in power and automation technologies. Under his leadership, ABB recovered from financial distress and achieved a record result in 2007. ABB's stock price rose from around 6 Swiss francs in January 2005, the time of Kindle's appointment as CEO, to around 25 Swiss francs in February 2008. According to the Financial Times, ABB's recovery qualifies as "case study of successful company restructuring". ${ }^{1}$ Nevertheless, on February 13, 2008, ABB surprisingly announced in an official statement that Fred Kindle

\footnotetext{
${ }^{1}$ http://www.ft.com/cms/s/0/5a5db304-da69-11dc-9bb9-0000779fd2ac.html
} 
would leave ABB "due to irreconcilable differences about how to lead the company". 2 The CFO of ABB, Michel Demaré, was appointed ad interim CEO, but at that time was also considered as a potential candidate for the position of permanent CEO. Several news agencies ${ }^{3}$ speculated that this decision was mainly caused by a power struggle with the president of the board, Hubertus von Gruenberg, regarding ABB's acquisition strategy. The departure of Fred Kindle was a big surprise to the financial community as everybody agreed that he was doing an outstanding job at ABB. Strikingly, the Financial Times referred to him as the "wunderkind chief executive". The fact that investors shared the same positive perception about Fred Kindle's performance is crucially captured by the stock-price reaction on the announcement date of his departure. In spite of the simultaneous announcements of (i) a record result for the year 2007, (ii) a doubling of the dividend (18\% in excess of the mean analyst dividend forecast) ${ }^{4}$, and (iii) upcoming share repurchases, the stock price dropped sharply by $5.14 \%$ on that very same day. According to Bloomberg, ABB's stock price lost interim about $10 \%$, which was the worst drop of the previous three years. While the academic literature has repeatedly stressed the beneficial effects of forced turnovers (e.g. Furtado and Rozeff, 1987; Denis and Denis, 1995; Kang and Shivdasani, 1996; Huson, Parrino, and Starks, 2001; Dherment-Ferere and Renneboog, 2002; Adams and Mansi, 2009), the example of Mr. Kindle suggests that the impact of a firing decision on shareholders' wealth might be negative and that the quality of the departing manager is a crucial variable in assessing the board's decision. ${ }^{5}$

A large part of prior research on CEO turnovers focuses on the relation between the CEO's performance and the turnover probability (e.g. Coughlan and Schmidt, 1985; Weisbach, 1988; Warner, Watts, and Wruck, 1988; Parrino, 1997; Suchard, Singh, and Barr, 2001; Defond and Hung, 2003; Jenter and Kanaan, 2010, among others). This strand of literature comes to the conclusion that there is a negative relation between the company's performance and the probability of a (forced) turnover. However, while statistically significant, this negative relation is generally considered to be economically weak (Brickley, 2003).

A second strand of literature which is of immediate relevance for the hypotheses studied in this paper investigates the impact of CEO turnovers on the company's performance. Contributions typically focus either on accounting-based or stock-price-based performance measures. Table 1 presents an overview of the most important papers that study the impact of CEO turnovers on shareholder value together with a summary of the main empirical findings. They differ with respect to the characteristics of the turnovers considered: (i) outside vs. inside successions (cf. Table 1, columns 7-8), (ii) forced vs. voluntary turnovers ${ }^{6}$ (cf. Table 1, columns 9-10), (iii) governance differences

\footnotetext{
${ }^{2}$ ABB Press Release: "ABB CEO Fred Kindle leaves company", available at http://www.abb.com.

${ }^{3}$ Amongst others Reuters, Bloomberg, Timesonline, Financial Times, Financial Times Deutschland, Handelsblatt and Handelszeitung covered the news regarding the departure of Fred Kindle at ABB.

${ }^{4}$ The mean analyst dividend forecast is obtained from I/B/E/S, Thomson Reuters.

${ }^{5}$ Despite the fact that the story of Mr. Kindle motivates very well this study and is a prime example of a CEO turnover that achieved broad media attention and had a shocking impact on investors, we should remark that this event is not included in the empirical analysis due to a "no-confounding-event" criterion applied in the construction of the sample. More precisely, the release of other valuation-relevant news (dividends and earnings announcements) on the date of the announcement of the dismissal of Mr. Kindle prevents us from using this event.

${ }^{6} \mathrm{~A}$ special category of management turnovers is represented by sudden deaths. The stock-price reactions in the aftermath of such key-executives' deaths is studied by Johnson, Magee, Nagarajan, and Newman (1985) and Worrell,
} 
(see Fisman, Khurana, and Rhodes-Kropf, 2005), and (iv) gender differences (see Lee and James, 2007; Coxbill, Sanning, and Shaffer, 2009).

[Table 1 about here]

The majority of studies that scrutinize the subsample of forced turnovers find that abnormal returns following firings are higher than those following voluntary turnovers (e.g. Furtado and Rozeff, 1987; Denis and Denis, 1995; Kang and Shivdasani, 1996; Huson, Parrino, and Starks, 2001; Dherment-Ferere and Renneboog, 2002; Adams and Mansi, 2009, among others). Borokhovich, Parrino, and Trapani (1996) report a significant positive abnormal performance after forced turnovers with an outside successor. Only Dedman and Lin (2002) detect significantly negative abnormal returns on average after $\mathrm{CEO}$ dismissals.

This paper challenges the widespread notion that firing decisions by board of directors represent positive news to investors. In particular, we argue that an important share of CEO firings are not in the interest of shareholders. While forced turnovers of skilled managers (as proxied by the prior relative company performance under his/her leadership) trigger positive and statistically significant abnormal returns (+5.73\% in a [-3 0$]$-day event window), forced turnovers of high-quality CEOs (35\% of all forced turnovers in our sample) are associated with negative abnormal returns $(-2.24 \%$ in a [-3 0]-day event window). Thus, shareholders seem to assess the quality of boards' firing decisions by considering the quality and skills of the departing CEO. If the prior relative stock performance under the departing CEO is positive, shareholders disfavor the board's decision and adjust downward their estimates about the value of the company. By studying the impact of information asymmetries (as proxied by analyst coverage) on abnormal returns, we rule out the hypothesis proposed by Ertugrul and Krishnan (2011) that the negative abnormal returns after dismissals of well-performing CEOs are due to the release of (supposedly superior) private information by the board of directors about the low quality of the outgoing CEO. Further, the opposite impact of CEO firings in dependence of the CEO quality is economically meaningful and statistically robust even after accounting for a variety of control variables, such as CEO age, company size, and governance changes directly related to the CEO turnover. It holds for (i) different event windows, (ii) time subperiods, (iii) alternative proxies of CEO quality, and (iv) a wide range of parametric and non-parametric test specifications. Finally, the relevance of prior performance in assessing the quality of the board's decision is also reflected in the subsequent long-term evolution of operating return on assets.

The remainder of the paper is structured as follows. Section 2 develops the hypotheses tested in this paper. Section 3 describes the data and the sample construction. In Section 4 we conduct the empirical analysis: After addressing the setup of the event-study (Subsection 4.1) and presenting general results related to the impact of CEO turnovers on abnormal stock returns (Subsection 4.2), we regress abnormal returns against various CEO-turnover variables (Subsection 4.3) and conduct extensive robustness checks (Subsection 4.4). Section 5 extends the analysis to the companies' operating performance. Finally, Section 6 provides a summary of the paper and concludes.

Davidson, Chandy, and Garrison (1986). 


\section{CEO Quality and Forced Turnovers}

The board of directors has the non-transferable and indefeasible duty of nomination and dismissal of the management of a company. The majority of empirical studies (cf. Table 1, column 9) report positive stock-price reactions around the announcements of CEO dismissals (or at least larger than those triggered by voluntary CEO departures):

- Furtado and Rozeff (1987): “...when dismissals occur, it is apparent that the benefits to the stockholder are quite great".

- Kang and Shivdasani (1996): “...returns are greater when turnover is forced than when turnover represents normal succession".

- Dherment-Ferere and Renneboog (2002): “...announcement of a forced CEO resignation is hailed favorably by the market".

- Adams and Mansi (2009): “...CEO turnover events are associated with increased stock returns, with forced and outside turnover events having the largest increases".

Scholars usually mention two theories to explain the positive stock-price reactions after CEO dismissals: (i) the improved management theory and (ii) the scapegoat theory. Both assume information asymmetry between the board of directors and managers.

According to the improved management theory of Huson, Malatesta, and Parrino (2004), boards assess the quality of CEOs by observing their performance. A CEO will be replaced if the realized performance is sufficiently low and the expected benefit of a turnover exceeds expected costs. According to this argument, investors should interpret a firing decision by the board as a positive signal about the quality differential separating the new from the incumbent CEO.

Under the scapegoat theory based on Holmström (1979), Shavell (1979), and Mirrlees (1976) firings of CEOs occur even though all managers are assumed to be identical in terms of quality. The threat of a dismissal merely serves to ensure adequate effort by the incumbent CEO. In equilibrium, all CEOs provide the same effort and low performance arises just by chance. In case of poor performance, the board of directors will fire a CEO just to maintain the threat of dismissal thereby creating the incentive to supply the optimal level of effort. Since in this model the poor performance leading to the dismissal of a CEO is simply the result of luck and not poor managerial quality or lack of effort, the fired CEO can be viewed as a scapegoat. Both theories assume that boards act in the shareholders' best and are successful in explaining the empirically established positive stock-market reaction following CEO dismissals.

In this paper, we challenge the notion that forced turnovers are homogeneous events that per se signal positive news to shareholders. In particular, we depart from the assumption that boards of directors act in the shareholders' best interest and conjecture that CEO firings have to be examined in tight connection with the quality of the departing CEO. Thus, we expect positive abnormal returns following a forced turnover of a low-quality manager and negative abnormal returns after a 
forced departure of a high-quality manager. While the former event reflects a good decision by the company's board of directors, the latter does not. Hence, the two main hypotheses tested in this study are as follows.

Hypothesis 1: The announcement of forced turnovers of low-quality CEOs yield positive abnormal stock returns.

Hypothesis 2: The announcement of forced turnovers of high-quality CEOs yield negative abnormal stock returns.

\section{Data}

\subsection{Sample Construction}

The data comprises CEO turnovers of companies in the Swiss Performance Index (SPI) between January 1998 and June 2009. The sample is hand-collected and initially consists of 347 turnovers at 184 companies. To construct the sample, we apply the following procedure. First, the complete list of CEO changes is obtained by collecting annual reports of all the companies included in the SPI since January 1998. Second, to identify the events and obtain the exact CEO-turnover announcement dates, the following sources are screened: (i) ad-hoc disclosures at the SIX Swiss Exchange, (ii) articles in leading Swiss financial and business newspapers (in particular, "NZZ", "Finanz und Wirtschaft", and "Handelszeitung"), (iii) company-specific news provided by Bloomberg, (iv) company Internet sites, and (v) selected Internet news sites. ${ }^{7}$

We include CEO-turnover events in the final sample if they cumulatively satisfy the following criteria:

(i) The date of the announcement, i.e. the first day investors can trade on the CEO-turnover information, has to be identifiable (this also includes the information on whether the announcement was made before or after the closing of the market);

(ii) The relevant details regarding the departing and the incoming CEO (age, succession type, and successor origin) have to be known;

(iii) There must be no confounding events, such as announcements of earnings, dividends, debt or equity offerings, corporate scandals, etc. in a seven-day time period centered around the turnover announcement. This criterion ensures that the analysis is conducted on "clean" CEOturnover events and that the stock-market reaction is not due to news unrelated to the CEO change. We also aim at excluding CEO-turnover events that might reveal new information

\footnotetext{
${ }^{7}$ Internet sites include www.news.ch, www.swissinfo.ch, and http://moneycab.presscab.com.
} 
privately held by the board about the quality of the departing CEO. This can be the case when a CEO firing reveals the existence of accounting fraud, corporate scandals, or serious negligence.

(iv) CEO turnovers must not be directly related to the takeover of a company;

(v) Finally, to guarantee a reasonably accurate estimation of the market model, we require the availability of a one-year stock-price history with at least 100 transaction days within this 250-day estimation period.

To get a first impression of the trading activity around CEO-turnover announcement dates, we consider the stock trading volume $(T V)$ as measured by the number of traded shares (Datastream item "Turnover by Volume"). Specifically, we compute the following standardized measure of abnormal trading volume:

$$
S T V_{i t}^{A}=\frac{T V_{i t}}{T V_{i t}^{N}}-1
$$

where $T V_{i t}$ is the realized trading volume of company $i$ at day $t$ (relative to the announcement day) and $T V_{i}^{N}$ is the normal, i.e. the expected, trading volume which is measured - in accordance with a constant-mean model - as the average trading volume between day -60 and day -11 : $T V_{i}^{N}=1 / 50 \cdot \sum_{t=-60}^{-11} T V_{i t} . S T V^{A}$ is easy to interpret because it represents the percentage increase in trading volume relative to a 50-day benchmark period before the event date.

Figure 1 depicts daily average abnormal trading volumes of all CEO-turnover announcements and the subsamples of forced and voluntary CEO changes. The graphs show a distinct increase of the average $S T V^{A}$ on the announcement date and the two following days. For the total sample (Figure 1a) the average trading volume on the event day is $+129.97 \%$ larger than the average trading volume in the estimation period. An increase in trading volume by almost $+200 \%$ can also be observed in Figure 1b for the subsample of forced departures. Thus, CEO-turnover news triggers a substantial trading activity among investors.

[Figure 1 about here]

\subsection{Explanatory Variables}

For all CEO-turnover events, we gather detailed information regarding the company, the departing $\mathrm{CEO}$, the new $\mathrm{CEO}$, and several turnover characteristics. The most important explanatory variables are the successor origin (inside vs. outside successions), the departure type (forced vs. voluntary departures $)^{8}$, and the managerial quality of the departing CEO as proxied by the prior

\footnotetext{
${ }^{8}$ In this paper, the terms firing, dismissal, and forced turnover are used interchangeably in spite of slightly different shades of meaning. In particular, we do not distinguish between straight dismissals and forced resignations because in both cases the CEO departure is a consequence of the board's will.
} 
stock performance relative to a broad stock-market index. ${ }^{9}$

In the related literature, the successor origin is measured by applying two alternative rules. According to the first rule, the new CEO is classified as an outsider if the appointment as CEO occurs on the same date as he/she joined the company; All other successors are classified as insiders (see Denis and Denis, 1995). According to the second rule, the new CEO is considered as an outsider if he/she has a working history in the relevant company of less than a year (see Parrino, 1997). In this paper, successors are classified as insiders or outsiders according to the former rule. However, applying the latter method does not qualitatively alter the major findings. In our sample, 75 CEO turnovers (36\% of the total sample) are classified as outside successions and 133 turnovers (64\% of the total sample) are classified as inside successions. Out of these 133 inside successions 25 are ad interim.

The division into forced and voluntary departures is also carried out following the methodology of Denis and Denis (1995). Based on the information provided by diverse media reports, such as leading Swiss financial and business newspapers, ad-hoc news, and company statements, a CEO turnover is classified as forced if it is accompanied by an internal conflict with the board. In those cases in which the turnover cannot be directly assigned either to the forced or the voluntary turnovers on the basis of the available data, we apply the following decision scheme: If the departing CEO is not over 64 years old and the newly appointed CEO is an outsider, the turnover is assigned to the subsample of forced departures. By applying this procedure, the sample of forced turnovers consists of 60 events ( $29 \%$ of the total sample) and the sample of voluntary turnovers includes 148 events $(71 \%))^{10}$

The quality of the departing manager is measured based on the relative stock performance of the company under his/her leadership. In particular, the relative stock performance is calculated against the Swiss Performance Index in a 250 trading-day period from day -260 to day -11 preceding the turnover announcement. Depending on the sign of the prior relative performance, the event is assigned either to subsample of low- or high-quality CEOs. In our sample, 118 turnovers (57\% of the total sample) are preceded by prior underperformance and 90 turnovers (43\%) by prior overperformance.

Table 2 provides a breakdown of the final sample by year and turnover characteristics. While there seem to be an overall increase in the total number of CEO turnovers over the years, this development is far from being steady and smooth.

\section{[Table 2 about here]}

It is worth noting that the percentages of outside successions and forced departures are, with $36 \%$ and $29 \%$ of the sample, respectively, slightly higher than those reported in recent studies. For

\footnotetext{
${ }^{9}$ As an alternative measure of CEO quality, we will use in Subsection 4.4 the prior stock performance relative to industry indexes.

${ }^{10}$ We actually obtain the same number of forced and voluntary turnovers by classifying turnovers according to the rule of Huson, Malatesta, and Parrino (2004). These authors classify turnovers for which no explicit firing reason could be found in the media as forced, if the departing CEO was younger than 60 and did not take a comparable position in another company.
} 
instance, Adams and Mansi (2009) report for the period between 1990 and 2000 29.4\% of outside replacements and $19.6 \%$ of forced turnovers; Parrino (1997) classifies only $15 \%$ of all turnovers in his sample as outside successions and only $13 \%$ as forced departures; Finally, Clayton, Hartzell, and Rosenberg (2005) examine the impact of CEO changes on the stock-price volatility and classify $20.6 \%$ of turnovers as outside successions and $17.4 \%$ as forced departures.

For the purpose of this study, it is important to emphasize that out of the 60 forced turnovers in our sample as many as 21 (or 35\%) concern CEOs who deliverd an above-average performance in the run-up to the dismissal. Interestingly, the large number of CEO dismissals with a positive prior stock performance is not a peculiarity of the Swiss market. In fact, Ertugrul and Krishnan (2011) point out that 37\% (49\%) of CEO dismissals in the US occur in the absence of negative raw (industry-adjusted) stock returns.

\subsection{Control Variables}

Abnormal stock returns induced by a turnover announcement might be influenced by a number of variables besides the origin of the new CEO, the performance of the departing CEO, and the turnover type. In the following, we consider control variables that are typically used in related studies (e.g. Huson, Malatesta, and Parrino, 2004, among others).

To account for the existence of effects related to the size of a company, we include as a control variable the logarithm of companies' total assets (SIZE) as provided by Datastream.

The age of the incumbent and the newly appointed CEO can also play an important role in determining the magnitude of the stock-price reaction. For example, if the incumbent CEO is close to retirement age, his/her departure might be anticipated and thus lack a strong surprise effect. In this case, the age of the departing CEO will have a dampening effect on the news impact. The appointment of a young CEO who is relatively unknown and potentially less experienced could also have a material effect on the stock-price reaction. To control for age-related effects, we include the logarithm of the age of the departing and incoming CEOs denoted by AGEDEP and AGEINC, respectively.

The replacement of the incumbent $\mathrm{CEO}$ with a new one might directly alter the governance structure of a company. This is the case when a dual-mandate structure is introduced or ceases to exist as a consequence of the CEO change. To account for corporate-governance changes that are directly related to the CEO turnover, we use as controls in cross-sectional regressions two dummy variables. DUALOLD assumes a value of one if the CEO turnover ends a dual-mandate structure and zero otherwise. DUALNEW assumes a value of one if the CEO turnover introduces a dual-mandate structure and zero otherwise. In our sample, we observe 18 corporate governance improvements (dual mandates that cease to exist) and 11 corporate governance deteriorations (newly created dual mandates). 


\section{Empirical Analysis}

\subsection{Methodology}

To measure the impact of CEO-turnover announcements on shareholder value, we apply standard event-study methodology. As usual, the tests rely on the assumption of market efficiency, i.e. that stock prices reflect all relevant information and thus quickly incorporate the effect related to CEO-turnover news. Consequently, we choose short-term event windows to measure the impact on stock prices. Following Brown and Warner (1985) and McWilliams and Siegel (1997) this event window should be long enough to capture the impact of the event, but short enough to minimize the influence of confounding effects unrelated to the CEO-turnover event. By employing different event windows ranging from one to four days we avoid relying on a specific, and possibly arbitrary, length of the event window. To account for potential information leakage, we let some event windows start before the CEO-turnover announcement date.

In accordance with the bulk of the literature on short-term event studies, we calculate abnormal stock returns in the event window by subtracting from realized stock returns the "normal" returns obtained by the market model. The parameters of the market model are estimated over a 250 trading-day period ending 11 days before the CEO-turnover announcement date. To make sure that the findings of the paper are not driven by inaccurately estimated parameters, the estimation of the market model is performed both by simple OLS and robust linear regressions (Huber, 1973). More specifically, in each iteration the weights are calculated by applying the bisquare function to the residuals from the previous iteration. Since the results of the two estimation procedures do not lead to qualitatively different results, for the sake of brevity, only the OLS regression results are reported in the paper. In addition to measuring the magnitude of mean and median abnormal returns, it is critical to determine their statistical significance. For this purpose we employ as baseline event-study tests the Standardized Cross-Sectional test by Boehmer, Musumeci, and Poulsen (1991) (henceforth simply denoted as Boehmer test) which specifically accounts for possible variance changes induced by the turnover event and the Wilcoxon Signed Rank test by Wilcoxon (1945) (henceforth simply denoted as Wilcoxon test) which is a non-parametric test and thus does not rely on specific distributional assumptions about abnormal stock returns.

\subsection{Abnormal Returns Around CEO Turnovers}

We start the empirical analysis by measuring abnormal returns (ARs) of four relevant samples: (i) the total sample of CEO turnovers, (ii) forced turnovers, (iii) forced turnovers of low-quality CEOs, and (iv) forced turnovers of high-quality CEOs. Table 3 reports both average and median abnormal returns with the corresponding Boehmer and Wilcoxon test statistics. ${ }^{11}$

\footnotetext{
${ }^{11}$ While standardized residuals from the market model - and not abnormal returns - are used in the calculation of the test statistics of Boehmer, Musumeci, and Poulsen (1991), in Table 3 we still report mean abnormal returns
} 
For the majority of the event windows considered, the average and median abnormal returns related to the whole sample (Panel A) are positive but not statistically significant. The evolution of cumulative ARs starting from day -3 is depicted in Figure 2a and shows a weak upward trend that never reaches statistical significance.

According to the improved management theory and prior empirical literature on forced turnovers, we expect the stock price to rise following decisions to fire a CEO. This prediction finds support in the results shown in Table 3, Panel B and depicted in the evolution of ARs in Figure 2b. The mean ARs for the subsample of forced turnovers are positive and significant on the announcement day and the event windows [-3 0$]$ and [ $\left[\begin{array}{ll}-1 & 0\end{array}\right]$ with values of $+1.70 \%,+2.87 \%$, and $+2.28 \%$, respectively. By comparing in Figure 2b the development of ARs of forced turnovers to ARs of voluntary turnovers one can visually capture the striking difference in the pattern of the two lines: positive and increasing for the former and very close to zero for the latter. For all tested event windows, ARs following voluntary turnovers are found to be insignificant at all conventional confidence levels (results not reported).

Panel C and D of Table 3 describe the impact of forced turnover of low- and high-quality CEOs. It stands out that - in accordance with hypothesis 1 of this paper - mean and median ARs following dismissals of low-quality CEOs are positive and significant for all event periods (except for the median AR on day -1). Conversely, the dismissal of high-quality CEOs is associated with negative stock-price reactions, which supports hypothesis 2 of this paper. The diverse reaction of investors to CEO dismissals in dependence of the prior stock performance is depicted in Figure 2c.

\section{[Table 3 about here]}

[Figure 2 about here]

To identify types of CEO turnovers that convey value-relevant news to shareholders, we analyze specific subsamples of CEO turnovers. Table 4, Panel A ranks the subsamples defined by one turnover characteristic according to the magnitude of the corresponding [-3 0]-ARs. Forced turnovers (FOR), the departure of low-quality CEOs (LQY), and outside successions (OUT) generate the largest and most significant ARs with respective values of $+2.87 \%,+2.07 \%$, and $+1.76 \%$. Departures of high-quality managers (HQY) trigger negative and statistically significant abnormal returns (mean $[-30]$-AR of $-1.30 \%, t$-value $=-1.80$ ).

To learn more about the information content of different types of CEO turnovers we extend the current analysis by defining further subsamples through the combination of different turnover characteristics. In a first step we calculate in Table 4, Panel B [-3 0]-ARs for all $12\left(\left(\begin{array}{l}3 \\ 2\end{array}\right) \cdot(2 \cdot 2)\right)$ possible subsamples that can be constructed by pairwise interrelating the three selection criteria (turnover type, successor origin, and CEO quality). Several findings deserve our attention.

First, the subsamples obtained by the pairwise intersection of outside successions (OUT), firings (FOR), and turnovers of high-quality CEOs (HQY) generate the largest ARs: $+6.57 \%$ ( $t$-value 
$=2.57),+5.73 \%(t$-value $=3.79)$, and $+3.80 \%(t$-value $=2.88)$ for OUT \& FOR; FOR \& LQY; and OUT \& LQY, respectively. Even when considering alternative event windows, those pairs of characteristics generate the strongest (and most significant) price reactions.

Second, it is of special interest to observe that forced turnovers rank 2nd and 12th (last) in this list. In particular, when considering forced turnovers of low-quality CEOs a mean AR as large as $+5.73 \%$ is achieved (associated with a $t$-value of 3.79). Conversely, forced turnovers of high-quality CEOs trigger negative and weakly significant ARs.

Finally, we note that outside CEOs yield positive abnormal returns only if the previous CEO was fired, not if he/she voluntary left the company.

If we define subsamples based on the interaction of all three turnover characteristics, we obtain a total of eight subsamples $\left(2^{3}\right)$. Again, Table 4, Panel C ranks those subsamples by their abnormal returns in the event window [-3 0$]$. Not surprisingly, the subsample with the most significant ARs (Boehmer $t$-value $=4.41$ ) is characterized by forced departures of low-quality CEOs substituted by firm outsiders. The mean [-3 0$]$-AR of the 14 events in this category amounts to $+10.58 \%$. The order of the subsamples defined in the columns R1, R2, and R3 in Table 4, Panel C reveal a interesting patterns. First, the prior performance (R1) is the single most important variable in deciding whether a turnover represents good or bad news. Turnovers of low-quality CEOs are always associated with positive ARs, while turnovers of high-quality CEOs trigger negative ARs. Second, column R2 impressively shows the amplifying and polarizing effect of forced turnovers in combination with low-, and high-quality CEOs (Hypotheses 1 and 2). The fact that a CEO is dismissed magnifies the positive (negative) abnormal returns associated with the departure of a high-quality (low-quality) CEO. Third, in column R3 subsamples with outside successors rank consistently above the corresponding subsamples with inside successors. Thus, while outside successors are ceteris paribus judged more positively than inside successors, the other variables (departure type and prior performance) seem to be more relevant in determining the impact on shareholder value of CEO-turnover news.

[Table 4 about here]

\subsection{Cross-Sectional Analysis of Abnormal Returns}

In this subsection we evaluate the cross-sectional information content of CEO turnovers by regressing ARs against a set of explanatory variables and controls. More precisely, we regress [-3 0]-ARs on an outside-succession dummy (OUT), a forced-turnover dummy (FOR), a CEOquality dummy (HQY) ${ }^{12}$, the size of the company measured as the logarithm of total assets (SIZE), the age of the departing CEO (AGEDEP), as well as the age of the incoming CEO (AGEINC). In addition, we include two dummy variables that account for changes in the governance structure of the company that are a direct consequence of the CEO turnover. DUALOLD assumes a value of

\footnotetext{
${ }^{12}$ In those cases in which the CEOs prior performance is modeled as a continuous variable it is denoted by QY instead of HQY.
} 
one if the CEO change ends a dual-mandate structure, and zero otherwise. DUALNEW assumes a value of one if the CEO change introduces a dual-mandate structure, and zero otherwise. Motivated by the previous findings about the double-edged impact of forced turnovers in dependence of the CEO quality, we add an interaction dummy variable, FOR $\times$ HQY, to explicitly capture this effect. In accordance with the hypothesis that the prior performance of a CEO is crucial in assessing the decision to fire him/her, we expect the coefficient of FOR $\times$ HQY to be negative and statistically significant.

The regression results are reported in Table 5. Regressions 1 to 3 are univariate regressions of ARs against a single turnover characteristic and thus simply replicate some of the results obtained by analyzing ARs of selected subsamples. For instance, the sum of the constant, -0.0031 , and the coefficient of the variable FOR, 0.0318, in Regression 2 of Table 5 is equivalent to the mean [-3 0]-AR for the subsample of forced turnovers, 2.87\%, in Table 4, Panel A. Nonetheless, performing cross-sectional regressions offers two decisive advantages: First, it allows to measure the impact of continuous variables (and not only dummy variables); Second, it allows to control for the effect of multiple variables on ARs and to isolate their impact.

Not surprisingly, in the univariate regressions the coefficients related to outside successions (OUT), forced turnovers (FOR), and the departure of high-quality CEOs (HQY) are all highly significant. In the multivariate regression with all nine explanatory variables (Table 5, Regression 4), the coefficients and significances of the variables OUT, FOR, and HQY experience only small changes. Surprisingly, the variable DUALNEW that indicates a governance worsening is positive and significant. This seems to suggest that in our sample the decision of setting up a dual mandate structure is usually taken in situations where the new CEO is considered to be particularly skilled and enjoys the support of financial markets. The size of the company (SIZE) has a slightly negative but insignificant effect on ARs. The coefficient related to the age of the departing manager (AGEDEP) is positive and the one related to the age of the incoming CEO (AGEINC) is negative, however, both of them are insignificant. $15.52 \%$ of the cross-sectional variance can be traced back to the nine variables. Most importantly for this study, the coefficient of FOR $\times$ HQY is negative and statistically significant at the $1 \%$ confidence level $^{13}$, which means that the stock market reaction is negatively related to the quality and success of the fired CEO.

\section{[Table 5 about here]}

To investigate in more detail shareholders' reactions to boards' personnel decisions, we regress in Table 6 the subsample of ARs related to CEO firings against the same set of explanatory variables and controls. ${ }^{14}$ Overall, the regression results reinforce the previous findings. First, abnormal stock returns are significantly lower when an outperforming CEO is fired. Second, outside appointments yield significantly higher abnormal returns than otherwise equal inside nominations. Third, a

\footnotetext{
${ }^{13}$ When computing Regression 4 based on other event windows, the signs of the coefficients remain unchanged and their significance levels are reasonably consistent.

${ }^{14}$ The variable DUALOLD is not included because in the sample there are no cases of forced turnovers that interrupt a dual-mandate structure.
} 
worsening of the governance structure due to the introduction of a dual-mandate is ceteris paribus associated with higher stock returns.

[Table 6 about here]

All the empirical results presented above indicate that the dismissal of a CEO does not per se represent good news and suggest that shareholders question whether boards of directors really act in their best interest. Shareholders assess the quality of the board's firing decision by considering the quality and skills of the departing CEO as proxied by the prior relative stock performance under his/her leadership. If the relative stock performance under the departing CEO is positive, shareholders disfavor the board's decision and adjust downward their estimates about the value of the company.

This interpretation of the results stands in partial contrast to the one provided in a recent article by Ertugrul and Krishnan (2011). They argue that CEO dismissals in the absence of poor prior stock performance should be viewed as proactive decisions by particularly attentive boards and refer to them as "early dismissals". Further, the presence of negative abnormal returns after dismissals of well-performing CEOs (early dismissals) is not seen as a market reaction to a wrong firing decision by the board of directors but - in line with theoretical considerations of Hermalin and Weisbach (1998) - as a consequence of a release of (superior) private information about the low quality of the outgoing CEO. Since both hypothesis are observationally equivalent, with the available empirical findings we cannot a priori rule out the view proposed by Ertugrul and Krishnan (2011).

To disentangle the two possible interpretations of the same empirical phenomenon, we test a hypothesis that follows from one of the two views but not from the other. If the dismissal of a CEO with a positive stock-price history is truly a revelation of superior private information to outside investors by the board of directors, then we should expect abnormal returns following such events to depend on the degree of asymmetric information between boards and investors. Thus, in cases of weak information asymmetry, the negative relation between abnormal returns and prior CEO performance should be less pronounced. On the contrary, if abnormal returns are not related to the release of private information by the board of directors, information asymmetry should have no impact on that relation. Several papers (e.g. Chang, Dasgupta, and Hilary, 2006; Bhushan, 1989) have shown that analysts coverage $(\mathrm{AC})$ is a good proxy for the degree of information (a)symmetry between boards and outside investors. Thus, we can use the number of financial analysts following a given stock to study whether and how information asymmetry affects the relation between abnormal returns following CEO dismissals and their prior relative stock performance:

$$
\begin{array}{r}
{[-30]-\mathrm{AR}=\underset{(0.16)}{0.0018}-\underset{(-4.67)}{0.083} \cdot \mathrm{QY}-\underset{(-0.08)}{0.0009} \cdot \mathrm{QY} \times \mathrm{AC}+\epsilon} \\
\quad \operatorname{adj} . R^{2}=34.19 \%
\end{array}
$$

where AC is the total number of financial analysts following a given stock (Bloomberg data item TOT_ANALYST_REC) and QY is the prior relative stock performance measured in the 250-day period preceding the turnover event. The fact that the coefficient of $\mathrm{QY} \times \mathrm{AC}$ is far from being 
statistically different from zero suggests that information asymmetry is not a crucial variable in explaining the negative abnormal returns following the dismissal of high-quality managers. At this point, it is important to keep in mind that the sample used in this study is specifically designed to focus on "clean" CEO turnover events. In the sample construction we intentionally exclude turnover events that apparently convey a strong signal about the quality of the incumbent CEO (e.g. firings revealing accounting fraud and other corporate scandals). Thus, the non-positive coefficient of $\mathrm{QY} \times \mathrm{AC}$ might be due to the exclusion of turnover events revealing new private information about the departing CEO.

\subsection{Robustness}

This subsection aims at proving the robustness of the results with respect to (i) econometric test specifications, (ii) time subperiods, and (iii) alternative proxies of CEO quality.

\section{Econometric Tests}

One major worry in event studies concerns the risk of detecting spurious abnormal returns. To shed light on this issue and gain insights about the reliability of the statistical inferences, we proceed in two steps. First, we perform empirical experiments that evaluate the performance of the two tests used in this paper - the Standardized Cross-Sectional test by Boehmer, Musumeci, and Poulsen (1991) and the Wilcoxon Signed Rank test by Wilcoxon (1945) - and compare them with a Bootstrap test. Second, we re-examine the most important event-study results by employing a battery of additional parametric and non-parametric event-study tests.

The one-sided (H1: $\overline{A R}>0$ ) bootstrap event-study test used in this paper is implemented in three steps. First, we calculate an ordinary $t$-value for the sample of abnormal returns: $t$-value $=$ $\overline{A R} / \sigma(A R) \sqrt{N}$, where $\overline{A R}$ is the mean abnormal return, $\sigma(A R)$ is the cross-sectional standard deviation of abnormal returns, and $N$ is the sample size (number of events). Second, we generate a distribution of 10,000 simulated $t$-values $(t$-value $r)$ under the null-hypothesis of zero abnormal returns by drawing market-model residuals (in-sample abnormal returns) from the 250-day estimation window preceding the event (from day -261 to day -11). More precisely, we generate 10,000 samples, each consisting of $N$ market-model residuals (one for each event) randomly-drawn from the estimation windows. For each of the 10,000 samples, we calculate the corresponding $t$-value $r$ as $\overline{A R}_{r} / \sigma\left(A R_{r}\right) \sqrt{N}$. Third, we calculate the one-sided $p$-value (H1: $\left.\overline{A R}>0\right)$ as the percentage of simulated $t$-values above the $t$-value of the original sample:

$$
p \text {-value }=(\# t \text {-value } r \geq t \text {-value }) / 10,000 .
$$

Bootstrap tests on $n$-day event windows are readily obtained by summing up $n$ consecutive marketmodel residuals starting on the randomly drawn event date within the 250-day estimation window.

In econometrics, the risk of erroneously rejecting the null hypothesis is referred to as error of type I. The probability of incurring into this error should be determined by the confidence level, 
$\alpha$. However, misspecified test statistics may lead to higher or lower rejection rates of true null hypotheses. The historical-simulation experiment used to assess the accuracy of the Boehmer and the Wilcoxon test is based on daily stock-price histories of all SPI companies in the time period from January 1990 to June 2009. It consists of two phases.

In the first phase, we generate 250 random samples of $N$ pseudo or "fake" CEO turnovers, each one representing a possible empirical sample of CEO turnovers. Clearly, since the turnovers did not actually take place, we know that the null hypothesis of zero abnormal returns is indeed true. Consequently, we expect the event-study tests to reject the null hypothesis with frequency $\alpha$. Each of the 250 samples is constructed as follows: First, we randomly draw with replacement $N(N \in\{10 ; 20 ; 50 ; 100 ; 200\})$ securities from the overall sample. Second, each sampled security gets assigned a randomly drawn pseudo-event day which also defines the estimation and the event window. In particular, in accordance with the event-study design employed in the paper, the estimation window covers the time period between -260 and -11 days before the event date. ${ }^{15}$

In the second phase, we conduct for each of the 250 pseudo-turnover samples a complete eventstudy test by (i) estimating the market model by OLS, (ii) calculating abnormal returns in the event window, and (iii) determining the rejection of the null hypothesis based on a particular test and confidence level, $\alpha$.

The rejection rates reported in Table 7 represent the percentage of samples for which abnormal returns are found to be significantly different from zero. Since for all three models the test statistics reject the null hypothesis with a frequency comparable to the significance levels, the Type I error rate is acceptable and the tests do not seem prone to detect spurious abnormal returns. Interestingly, the rather involved Bootstrap event-study test does not seem to deliver better results than the other two test statistics.

\section{[Table 7 about here]}

To further ensure the robustness of the findings, we re-examine the empirical results by implementing an additional battery of parametric and non-parametric event-study tests. The parametric methods include the Traditional test by Brown and Warner (1980), the Portfolio test by Brown and Warner (1980), a test that accounts for first-order autocorrelation in abnormal stock returns by Ruback (1982), and the Standardized-Residual test by Patell (1976). The non-parametric tests employed in this study include the mentioned Bootstrap test, the Corrado Rank test by Corrado (1989), and the Generalized Rank test by Kolari and Pynnonen (2008). The non-parametric test statistics have the advantage of avoiding the assumption of a specific distribution for the abnormal returns. Table 8 reports $t$-values associated with different tests, event windows, and CEO-turnover subsamples. It is reassuring to observe that the significant results obtained earlier for forced departures are even stronger when considering the additional tests (Panel B). The significant positive abnormal returns in connection with forced turnovers of low-quality CEOs (Hypothesis 1) is confirmed by all test statistics (Panel C). Finally, the majority of tests indicate significant negative

\footnotetext{
${ }^{15}$ To estimate the market model, we require the companies to be a member of the Swiss Performance Index during all 261 days prior to the randomly drawn event date. If this condition is not fulfilled a new pseudo event day is randomly assigned to this security. This cycle continues until a complete history of security returns is generated.
} 
returns around forced turnovers of high-quality CEOs (Hypothesis 2, Panel D).

[Table 8 about here]

\section{Time Subperiods}

To test the stability of the results over time, we divide the sample into two subperiods of equal length (1998-2003 and 2004-2009) and re-run cross-sectional regressions for the sample of all CEO turnovers and the subsample of CEO firings. Regardless of the time subsample (almost) all the coefficients in Table 9 have the expected sign (except for HQY in the first regression). In the regressions based on all CEO turnovers, the coefficients of FOR ${ }^{*} \mathrm{HQY}$ are consistently negative and statistically significant. Similarly, in the regressions based on the subsample of forced CEO turnovers prior performance enters the regression with a negative and significant coefficient. Thus, the dependence of the announcement impact of forced turnovers on the prior performance is a feature that is present in both subperiods. Finally, the cross-sectional regressions in the subperiod 1998-2003 have a higher explanatory power in terms of $R^{2}$ than those in the subperiod 2004-2009.

[Table 9 about here]

\section{Alternative Proxies of CEO Quality}

As a further robustness check, we test whether the results of the cross-sectional regressions obtained in Table 6, regression 3 also hold for alternative performance-based proxies of CEO quality. In a first robustness check, the estimation period of the prior performance is varied and the crosssectional regressions are re-calculated by employing estimation periods of 50, 125, 250 (default), 375, and 500 days (Table 10). For all estimation periods the coefficient of the CEO-quality variable is negative and statistically significant.

[Table 10 about here]

In a second robustness check, we consider, as an alternative measure of CEO quality, the prior relative stock performance computed against an industry index (instead of a broad stock-market index). The companies are classified according to 15 different industry sectors as provided by Datastream. ${ }^{16}$ Following this calculation, QYIA is the prior realized relative stock performance measured against the corresponding industry index during the one-year period preceding the CEOturnover announcement. Clearly, the two prior-performance measures that serve as a proxy of managerial CEO quality (QY and QYIA) are not identical. However, these measures do not lead to a

\footnotetext{
${ }^{16}$ The industries are: health care, utilities, travel \& leisure, retail, media, chemicals, basic resources, banks, insurance, financial services, technology, construction \& material, industrials, food \& beverage, and personal goods.
} 
very different classification of CEOs: $81.3 \%$ (81.7\%) of (forced) managers classified as "high-quality" based on industry-adjustment are also "high-quality" based on the standard market adjustment. Table 11 shows that in all four regressions the performance variable QYIA still has a negative coefficient and is highly significant. Thus, the importance of CEO quality in explaining the stockmarket reaction does not crucially depend on the specific choice of the CEO-quality proxy.

[Table 11 about here]

\section{Operating Performance}

As mentioned in the introduction, accounting-based performance measures can be used as an alternative way to assess the value of a CEO turnover. Several papers investigate the impact of CEO changes on key accounting-based performance measures (e.g. Denis and Denis, 1995; Khurana, 2001; Dedman and Lin, 2002; Huson, Malatesta, and Parrino, 2004; Fisman, Khurana, and RhodesKropf, 2005; Hillier and McColgan, 2005; Dezso, 2007; Dimopoulos and Wagner, 2010). Typically, these papers evidence that a forced CEO-turnover is preceded by deteriorating accounting figures which improve after the new CEO takes up his/her position.

In this section of the paper, we investigate whether the quality of the dismissed CEO is an important variable in explaining the subsequent changes in operating performance. Thus, we investigate whether the development of the operating performance of a company reflects the short-term stock-price impact of CEO-turnover announcements. If we assume that markets are efficient, abnormal stock returns should reflect investors' perceptions about fundamental changes in the value of the company. According to basic valuation principles, the fundamental value of a company results from the sum of all the expected future free cash flows discounted at the appropriate risk-adjusted interest rate. Thus, changes in the value of a company reflect either (i) changes in the relevant discount rate or (ii) changes in the expected future cash flows (or both). If we rule out that a CEO turnover has an impact on the relevant discount rate, ${ }^{17}$ the difference in the company valuation before and after the CEO-turnover announcement will solely reflect changes in the expected cash flows and thus in the future operating performance of that company.

\subsection{Changes in OROA}

The long-term impact of CEO turnovers is measured using the operating return on assets (OROA). We calculate the operating return on total assets in period $t, \mathrm{OROA}_{t}$, as the ratio of operating income (Datastream item 137) and book value of total assets (Datastream item 392). We do not consider the return on assets in the financial year of the CEO turnover because it is affected

\footnotetext{
${ }^{17} \mathrm{~A}$ change in the discount rate would be appropriate if the average successor reduced the systematic risk of a company or had an impact on the market risk premium. A comparison of betas before and after the event date seems to rule out the first hypothesis, while the latter appears implausible.
} 
by both the old and the new CEO. ${ }^{18}$ Therefore, $\mathrm{OROA}_{0}$ indicates the operating return on assets of the financial year ending before the CEO turnover and $\mathrm{OROA}_{+1}$ denotes the return corresponding to the first full-time year under the lead of the new CEO.

The development of median OROA changes is depicted in Figure 3. Similar to Denis and Denis (1995), Huson, Malatesta, and Parrino (2004), and Dezso (2007), we find that forced CEO turnovers (Figure 3b) are generally preceded by deteriorating operating performance and followed by a steady increase in profitability. Strikingly, while the same U-shape pattern in OROAs can be observed for the subsample of low-quality CEO dismissals (Figure 3c), the subsample of forced departures of high-quality CEOs is characterized by a completely different OROA development: The median change in operating performance is positive and increasing before the firing and gets negative afterward.

[Figure 3 about here]

Table 12 provides econometric tests on OROA changes. Panel B of this table confirms that OROAs associated with for forced CEO turnovers significantly worsen in the run-up to the turnover and improve afterward. For the purposes of this paper, it is particularly interesting to compare OROA changes following forced departures of low-quality CEOs (Panel C) to OROA changes following forced departures of high-quality CEOs (Panel D). Three considerations can be made. First, similar to Panel A (total sample) and Panel B (forced turnovers), the dismissal of a low-quality CEO is (not surprisingly) preceded by decreasing operating performance. Second, operating performance does not significantly change before the dismissal of a high-quality CEO. Third, and most importantly, changes in operating performance after a CEO turnover crucially differ depending on the quality of the dismissed CEO. Both mean and median OROAs increase after the firing of a lowquality CEO. Especially, in the [0 2]-year event window, mean and median OROA changes amount to $+8.82 \%$ and $+2.13 \%$ with $t$-values of $=2.29$ and $=2.35$. On the contrary, mean and median OROA changes following the firing of high-quality CEOs tend to be negative, although statistical significance is weak. Thus, the previously-detected difference in abnormal returns following the dismissal of low- and high-quality CEOs seem to be reflected in the evolution of firm profitability.

[Table 12 about here]

\subsection{Cross-Sectional Analysis of Operating Performance}

To refine the analysis on the importance of CEO quality in explaining the impact of turnovers on the operating performance, we consider different measures of abnormal operating performance

\footnotetext{
${ }^{18}$ It is often argued that departing CEOs have incentives to artificially increase reported earnings in a last attempt to keep their position. Conversely, a newly appointed CEO has an incentive to reduce reported earnings to credit the predecessor with poor performance and obtain the merits of the subsequent increase in performance. The second mentioned discretionary behavior is known in the literature as "earnings bath" (Elliott and Shaw, 1988; DeAngelo, 1988; Murphy and Zimmerman, 1993; Pourciau, 1993; Wells, 2002).
} 
and perform cross-sectional regressions against the same explanatory and control variables used in the analysis of abnormal stock returns (Section 4). Abnormal operating performance is obtained by comparing the realized operating performance of a company, $\mathrm{OROA}_{t}$, with a measure of its normal, or expected, operating performance. We follow Barber and Lyon (1996) and consider three models to determine the expected operating performance of a company. Accordingly, we obtain three different measures for the abnormal operating performance:

1. Lagged-Adjusted OROA ${ }^{19}: \mathrm{LA}_{-} \mathrm{OROA}_{i, t}=\mathrm{OROA}_{i, t}-\mathrm{OROA}_{i, t-1}$

2. Industry-Adjusted OROA: IA-OROA $i, t=\mathrm{OROA}_{i, t}-\overline{\mathrm{OROA}}_{i, t}^{I}$

3. Lagged-Industry-Adjusted OROA: LIA-OROA $i, t=\mathrm{OROA}_{i, t}-\left(\mathrm{OROA}_{i, t-1}+\Delta \overline{\mathrm{OROA}}_{i, t}^{I}\right)$

where $\overline{\mathrm{OROA}}_{i, t}^{I}$ is the median industry OROA (without considering company $i$ ) and $\Delta \overline{\mathrm{OROA}}_{i, t}^{I}$ is the change in the median industry OROA from year $t-1$ to year $t$. The median OROA of an industry is calculated starting from a sample of current and past SPI companies. First, we consider all companies with the same "Sector 4" industry code of Datastream for which financial statements are available. If less than three companies are in the same "Sector 4" industry, we consider all companies in the larger "Sector 3" industry group. If even with this broader industry definition we cannot find at least three companies with available OROAs, we use all SPI companies.

Table 13 shows the results of regressing abnormal OROAs against a set of explanatory variables and controls. The samples used in the cross-sectional analysis of abnormal operating performance are smaller than those used for the event studies on abnormal returns because of the lack of accounting data for some of the companies in our sample. The fact that in all regressions the coefficients of FOR ${ }^{*} \mathrm{HQY}$ are negative is consistent with the view that the performance impact of forced CEO turnovers is much lower when a manager with a positive performance record is dismissed. In this respect, the cross-sectional regressions based on operating performance reinforce the importance of the CEO quality in assessing the success of a board's firing decision. The slightly lower significances of the FOR ${ }^{*} \mathrm{HQY}$ coefficients in the cross-sectional regressions based on abnormal OROAs (see Table 13) than in those with abnormal returns (see Table 5) is likely due to the large number of confounding shocks affecting the long-term development of operating performance.

[Table 13 about here]

\section{Summary and Conclusions}

We investigate the information content of CEO-turnover announcements by analyzing abnormal stock returns and operating performance in a hand-collected sample of 208 "clean" turnover events

\footnotetext{
${ }^{19}$ The lagged-adjusted OROA (LA-OROA) corresponds to the changes in OROA used in Subsection 5.1 and plotted in Figure 3.
} 
between January 1998 and June 2009. Unlike the majority of previous studies, we show that forced turnovers do not per se represent positive news to shareholders. On the contrary, investors seem to critically assess the board's firing decision by considering the company's prior relative stock performance under the departing CEO as a proxy for his/her quality. Forced turnovers of lowquality CEOs are associated with positive and significant abnormal returns. On the contrary, the dismissal of outperforming CEOs - an event that occurs in as many as $35 \%$ of all forced turnovers in our sample - triggers on average negative abnormal stock returns.

The different market reaction in dependence of the quality of the dismissed CEO is confirmed in multivariate cross-sectional regressions, holds for different time sub-periods, and is robust to various event-test specifications and proxies of CEO quality. By studying the impact of information asymmetries (measured by analyst coverage) on abnormal returns, we rule out the hypothesis that the negative abnormal returns after dismissals of well-performing CEOs are due to the release of negative information privately held by the board of directors. Finally, we show that the CEO quality of dismissed managers is also reflected in the development of companies' operating return on assets. While the operating performance significantly increases after the dismissal of low-quality CEOs, it does not improve after the forced departure of high-quality CEOs.

To conclude, this paper suggests that a large portion of forced CEO turnovers, namely those concerning CEOs with a positive performance record, trigger negative abnormal returns and do not improve companies' operating performance. Thus, those firing decisions do not comply with the shareholders' best interests.

\section{References}

Adams, J. C., And S. A. MAnsi (2009): "CEO turnover and bondholder wealth," Journal of Banking and Finance, 33, 522-533.

BARBER, B. M., AND J. D. LyON (1996): "Detecting abnormal operating performance: The empirical power and specification of test statistics," Journal of Financial Economics, 41, 359399.

Beatty, R. P., And E. J. ZaJaC (1987): "CEO change and firm performance in large corporations: Succession effects and manager effects," Strategic Management Journal, 8(4), 305-317.

Bertrand, M., And A. Schoar (2003): "Managing with style: The effect of managers on firm policies," The Quarterly Journal of Economics, 118(4), 1169-1208.

Bhushan, R. (1989): "Firm characteristics and analyst following," Journal of Accounting and Economics, 11, 255-275.

Boehmer, E., J. Musumeci, And A. B. Poulsen (1991): "Event-study methodology under conditions of event-induced variance," Journal of Financial Economics, 30, 253-272.

Borokhovich, K., R. Parrino, and T. Trapani (1996): "Outside directors and CEO selection," Journal of Financial and Quantitative Analysis, 31, 337-355. 
Brickley, J. A. (2003): "Empirical research on CEO turnover and firm-performance," Journal of Accounting and Economics, 36, 227-233.

Brown, S., AND J. WARnER (1980): "Measuring security price performance," Journal of Financial Economics, 8, 205-258.

(1985): "Using daily stock returns: The case of event studies," Journal of Financial Economics, 14, 3-31.

Chang, X., S. Dasgupta, And G. Hilary (2006): "Analyst coverage and financing decisions," Journal of Finance, 61(6), 3009-3048.

Clayton, M. C., J. C. Hartzell, and J. Rosenberg (2005): "The impact of CEO turnover on equity volatility," Journal of Business, 78, 1779-1808.

Cools, K., And C. M. van PRAaG (2007): "The value relevance of top executive departures: Evidence from the Netherlands," Journal of Corporate Finance, 13, 721-742.

Corrado, C. J. (1989): "A nonparametric test for abnormal security price performance in event studies," Journal of Financial Economics, 23, 385-395.

Coughlan, A., and R. Schmidt (1985): "Executive compensation, management turnover, and firm performance: An empirical investigation," Journal of Accounting and Economics, 7, 43-66.

Coxbill, A. L., L. W. Sanning, and S. Shaffer (2009): "Market reaction to the announcement of a male-to-female CEO turnover," CAMA Working Paper Series.

Dahya, J., A. A. Lonie, and D. M. Power (1998): "Ownership structure, firm performance and top executive change: An analysis of UK firms," Journal of Business Finance $\&$ Accounting, $25,1089-1118$.

Dahya, J., And J. J. McConnell (2005): "Outside directors and corporate board decisions," Journal of Corporate Finance, 11, 37-60.

Danisevska, P., A. De Jong, and M. Rosellon (2003): "Disciplining managers: Evidence from two-tier boards," Working Paper.

DeAngelo, L. E. (1988): "Managerial competition, information costs, and corporate governance: The use of accounting performance measures in proxy contests," Journal of Accounting and Economics, 10, 3-36.

Dedman, E., And S.-J. Lin (2002): "Shareholder wealth effects of CEO departures: Evidence from the UK," Journal of Corporate Finance, 8, 81-104.

Defond, M., And M. Hung (2003): "Investor protection and corporate governance: Evidence from worldwide CEO turnover," Journal of Accounting Research, 42(2), 269-312. 
Denis, D. J., And D. K. Denis (1995): "Performance changes following top management dismissals," The Journal of Finance, 50, 1029-1057.

DEzso, C. L. (2007): "Entrenchment and changes in performance following CEO turnover," Working Paper.

Dherment-Ferere, I., And L. Renneboog (2002): "Share price reactions to CEO resignations and large shareholder monitoring in listed French companies," In: McCahery, J., et al. (Eds.), Convergence and Diversity of Corporate Governance Regimes and Capital Markets. Oxford University Press, pp. 297-324.

Dimopoulos, T., And H. Wagner (2010): "Cause and effect in CEO changes," Working Paper.

Elliott, J. A., And W. H. Shaw (1988): "Write-Offs as accounting procedures to manage perceptions," Journal of Accounting Research, 26, 91-119.

Ertugrul, M., And K. Krishnan (2011): "Can CEO dismissals be proactive?," Journal of Corporate Finance, forthcoming.

Fisman, R., R. Khurana, and M. Rhodes-Kropf (2005): "Governance and CEO turnover: Do something or do the right thing?," Working Paper.

Furtado, E. P., And M. S. RozefF (1987): "The wealth effects of company initiated management changes," Journal of Financial Economics, 18, 147-160.

Hermalin, B. E., And M. S. Weisbach (1998): "Endogenously chosen boards of directors and their monitoring of the CEO," American Economic Review, 88(1), 96-118.

Hillier, D., And P. MCCOlgan (2005): "Firm performance, entrenchment and CEO succession in family-managed firms," Working Paper.

Holmström, B. (1979): "Moral hazard and observability," The Bell Journal of Economics, 10(1), $74-91$.

Huber, P. J. (1973): "Robust regression: Asymptotics, conjectures, and monte carlo," Annals of Statistics, 1(5), 799-821.

Huson, M. R., P. H. Malatesta, and R. Parrino (2004): "Managerial succession and firm performance," Journal of Financial Economics, 74, 237-275.

Huson, M. R., R. Parrino, and L. T. Starks (2001): "Internal monitoring mechanisms and CEO turnover: A long-term perspective," Journal of Finance, 56, 2265-2297.

Jenter, D., AND F. KAnAAN (2010): "CEO turnover and relative performance evaluation," Working Paper. 
Johnson, W. B., R. P. Magee, N. J. Nagarajan, and H. A. Newman (1985): "An analysis of the stock price reaction to sudden executive deaths: Implications for the managerial labor market," Journal of Accounting and Economics, 7, 151-174.

Kang, J. K., And A. Shivdasani (1996): "Does the Japanese governance system enhance shareholder wealth? Evidence from the stock-price effects of top management turnover," The Review of Financial Studies, 9, 1061-1095.

Khanna, N., and A. B. Poulsen (1995): "Managers of financially distressed firms: Villains or scapegoats?," The Journal of Finance, 50, 919-940.

Khurana, R. (2001): “The performance consequences of CEO turnover," Working Paper, MIT and Harvard University.

Kolari, J., and S. Pynnonen (2008): "Generalized rank test for testing cumulative abnormal returns in event studies," Working Paper.

Lee, P., And E. H. James (2007): "She'-E-Os: Gender effects and stock price reactions to the announcements of top executive appointments," Strategic Management Journal, 28(3), 227-241.

Mahajan, A., And S. Lummer (1993): "Shareholder wealth effects of management changes," Journal of Business Finance and Accounting, 20(3), 393-410.

McWilliams, A., And D. Siegel (1997): "Event studies in management research: Theoretical and empirical issues," The Academy of Management Journal, 40, 626-657.

Mirrlees, J. A. (1976): "The optimal structure of incentives and authority within an organization," The Bell Journal of Economics, 7(1), 105-131.

Murphy, K. J., And J. L. Zimmerman (1993): "Financial performance surrounding CEO turnover," Journal of Accounting and Economics, 16, 273-315.

Neumann, R., and T. Voetmann (2005): "Top executive turnovers: Separating decision and control rights," Managerial and Decision Economics, 26, 25-37.

PARK, S., And M. S. Rozeff (1994): "The role of outside shareholders, outside boards, and management entrenchment in CEO selection," Working Paper.

PARRINO, R. (1997): "CEO turnover and outside succession: A cross-sectional analysis," Journal of Financial Economics, 46, 165-197.

PAtell, J. M. (1976): "Corporate forecasts of earnings per share and stock price behavior: Empirical tests," Journal of Accounting Research, 14, 246-276.

Pourciau, S. (1993): "Earnings management and nonroutine executive changes," Journal of Accounting and Economics, 16, 317-336. 
Reinganum, M. R. (1985): "The effect of executive succession on stockholder wealth," Administrative Science Quarterly, 30, 46-60.

RuBACK, R. (1982): "The effect of discretionary price control decisions on equity values," Journal of Financial Economics, 10, 83-106.

Setiawan, D. (2008): "An analysis of market reaction to CEO turnover announcement: The case in indonesia," International Business 85 Economics Research Journal, 7, 119-128.

Shavell, S. (1979): "Risk sharing and incentives in the principal and agent relationship," Journal of Business, 10(1), 55-73.

Shen, W., And A. A. Cannella (2003): "Will succession planning increase shareholder wealth? Evidence from investor reactions to relay CEO successions," Strategic Management Journal, 24(2), 191-198.

Suchard, J., M. Singh, And R. BARr (2001): "The market effects of CEO turnover in Australian firms," Pacific-Basin Finance Journal, 9, 1-27.

Warner, J. B., R. L. Watts, And K. H. Wruck (1988): "Stock prices and top management changes," Journal of Financial Economics, 20, 461-492.

Weisbach, M. (1988): "Outside directors and CEO turnover," Journal of Financial Economics, 20, 431-460.

Wells, P. (2002): "Earnings management surrounding CEO changes," Accounting and Finance, 42(2), 169-193.

Wilcoxon, F. (1945): "Individual comparisons by ranking methods," Biometrics Bulletin, 1(6), $80-83$.

Worrell, D. L., W. N. Davidson, P. Chandy, and S. L. Garrison (1986): "Management turnover through deaths of key executives: Effects on investor wealth," The Academy of Management Journal, 29, 674-694.

Worrell, D. L., W. N. Davidson, and J. L. Glascock (1993): "Stockholder reactions to departures and appointments of key executives attributable to firings," The Academy of Management Journal, 36, 387-401. 
Table 1: Related Empirical Literature on CEO Turnovers

This table provides an overview of important empirical contributions that study the impact of CEO-turnover announcements on shareholder value. The table provides information about the market investigated (Market), the time period covered by the empirical sample (Years), the executive position under investigation (Pos.), the number of management turnovers considered in the widest sample (Sample), the event window used for calculating abnormal returns (Window), and test result related Succession Type (OUT denotes outside and INS inside successions) and Departure Type (FOR denotes forced and VOL voluntary turnovers). In spite of the lear-cut classification provided in this table, the studies can differ in the specific mechanisms used to classify turnovers. Furthermore, in the last column we indicate whether the study also examines the impact of CEO turnovers on return on assets $(R O A) .{ }^{* * *}, * *$, and $*$ denote statistical significance at the $1 \%, 5 \%$, and $10 \%$ confidence level, respectively, in a two-tailed test.

\begin{tabular}{|c|c|c|c|c|c|c|c|c|c|c|}
\hline \multirow[t]{2}{*}{ Authors } & \multirow[t]{2}{*}{ Market } & \multirow[t]{2}{*}{ Years } & \multirow[t]{2}{*}{ Pos. } & \multirow[t]{2}{*}{ Sample } & \multirow[t]{2}{*}{ Window } & \multicolumn{2}{|c|}{ A1: Succession Type } & \multicolumn{2}{|c|}{ A2: Departure Type } & \multirow[t]{2}{*}{ ROA } \\
\hline & & & & & & OUT & INS & FOR & VOL & \\
\hline Reinganum (1985) & USA & 1978-1979 & Top & 353 & [0] & $1.17 \% * *$ & $-0.13 \%$ & - & - & - \\
\hline Beatty and Zajac (1987) & USA & 1979-1980 & $\mathrm{CEO}$ & 209 & {$[0]$} & $0.10 \%$ & $0.00 \%$ & - & - & - \\
\hline Furtado and Rozeff (1987) & USA & 1975-1982 & Top & 323 & {$\left[\begin{array}{ll}0 & 1\end{array}\right]$} & $0.72 \%$ & $1.05 \% * * *$ & $1.03 \% * *$ & - & - \\
\hline Warner, Watts, and Wruck (1988) & USA & $1963-1978$ & Top & 230 & {$\left[\begin{array}{ll}-1 & 0\end{array}\right]$} & $0.34 \% * *$ & - & $0.14 \%$ & - & - \\
\hline Mahajan and Lummer (1993) & USA & $1972-1983$ & Top & 498 & {$\left[\begin{array}{ll}-1 & 0\end{array}\right]$} & - & - & $-0.73 \% *$ & $0.21 \%$ & - \\
\hline Worrell, Davidson, and Glascock (1993) & USA & 1963-1987 & Top & 62 & {$\left[\begin{array}{ll}-1 & 0\end{array}\right]$} & $-1.17 \%$ & $0.83 \%$ & $0.38 \%$ & - & - \\
\hline Park and Rozeff (1994) & USA & 1979-1986 & $\mathrm{CEO}$ & 385 & {$\left[\begin{array}{ll}-1 & 0\end{array}\right]$} & $0.61 \%$ & $-0.34 \%$ & - & - & $\checkmark$ \\
\hline Denis and Denis (1995) & USA & $1985-1988$ & $\mathrm{CEO}$ & 328 & {$\left[\begin{array}{ll}-1 & 0\end{array}\right]$} & - & - & $2.50 \% * * *$ & $0.61 \%$ & $\checkmark$ \\
\hline Khanna and Poulsen (1995) & USA & 1980-1990 & Top & 121 & {$\left[\begin{array}{ll}-1 & 0\end{array}\right]$} & $-0.26 \%$ & $0.00 \%$ & - & - & - \\
\hline Huson, Parrino, and Starks (2001) & USA & 1971-1995 & $\mathrm{CEO}$ & 854 & {$\left[\begin{array}{ll}-2 & 2\end{array}\right]$} & $2.49 \% * * *$ & - & $2.02 \% * * *$ & - & - \\
\hline Shen and Cannella (2003) & USA & 1988-1997 & $\mathrm{CEO}$ & 177 & {$\left[\begin{array}{ll}-1 & 1\end{array}\right]$} & $1.95 \% * * *$ & - & - & - & - \\
\hline Adams and Mansi (2009) & USA & $1973-2000$ & $\mathrm{CEO}$ & 674 & {$\left[\begin{array}{ll}-1 & 1\end{array}\right]$} & $2.42 \% * * *$ & $0.15 \%$ & $2.43 \% * * *$ & $0.27 \% * *$ & - \\
\hline Dahya, Lonie, and Power (1998) & UK & 1989-1992 & Top & 105 & {$\left[\begin{array}{ll}-1 & 0\end{array}\right]$} & - & - & $0.12 \% * *$ & $-0.02 \%$ & - \\
\hline Dedman and Lin (2002) & UK & 1990-1995 & $\mathrm{CEO}$ & 251 & {$\left[\begin{array}{ll}-1 & 1\end{array}\right]$} & - & - & $-3.40 \% * * *$ & $0.13 \%$ & $\checkmark$ \\
\hline Dahya and McConnell (2005) & UK & 1988-1999 & $\mathrm{CEO}$ & 523 & {$\left[\begin{array}{ll}-1 & 0\end{array}\right]$} & $0.79 \% * * *$ & $0.20 \%$ & - & - & - \\
\hline Hillier and McColgan (2005) & UK & 1993-1998 & $\mathrm{CEO}$ & 462 & {$\left[\begin{array}{ll}-1 & 1\end{array}\right]$} & - & - & $11.82 \%$ & $0.92 \% * *$ & $\checkmark$ \\
\hline Dherment-Ferere and Renneboog (2002) & FR & 1988-1992 & $\mathrm{CEO}$ & 92 & {$\left[\begin{array}{ll}-1 & 0\end{array}\right]$} & - & - & $0.50 \%$ & $0.40 \%$ & - \\
\hline Kang and Shivdasani (1996) & JP & 1985-1990 & $\mathrm{CEO}$ & 432 & {$\left[\begin{array}{ll}-1 & 0\end{array}\right]$} & $0.95 \% * *$ & $0.38 \% * *$ & $1.02 \% * *$ & $0.40 \% * *$ & - \\
\hline Setiawan (2008) & ID & 1992-2003 & $\mathrm{CEO}$ & 59 & {$[0]$} & $0.90 \%$ & $-2.30 \%$ & $-1.20 \%$ & $0.00 \%$ & - \\
\hline Neumann and Voetmann (2005) & DK & 1994-1998 & $\mathrm{CEO}$ & 81 & {$\left[\begin{array}{ll}-1 & 1\end{array}\right]$} & - & - & $1.10 \% * *$ & $-1.00 \% * *$ & - \\
\hline Danisevska, de Jong, and Rosellon (2003) & NL & 1993-1999 & $\mathrm{CEO}$ & 84 & {$\left[\begin{array}{ll}0 & 1\end{array}\right]$} & - & - & $-0.54 \%$ & - & - \\
\hline Cools and van Praag (2007) & NL & 1991-1999 & Top & 227 & {$\left[\begin{array}{ll}0 & 1\end{array}\right]$} & - & - & $0.97 \%$ & - & - \\
\hline
\end{tabular}


Table 2: Statistics on CEO Turnovers in the Sample

This Table provides a breakdown of the final sample by year and turnover characteristics. Total Turnover indicates the number of all CEO turnovers during a particular year. Successor Origin is subdivided into the categories Insider (INS) and Outsider (OUT). Departure Type is subdivided into the categories Forced (FOR) and Voluntary (VOL). CEO quality is subdivided into the categories low-quality (LQY) and high-quality (HQY). CEO quality is measured by the prior relative stock-price performance relative to a broad market index (SPI) in the one-year period preceding the CEO-turnover announcement date.

\begin{tabular}{|c|c|c|c|c|c|c|c|}
\hline \multirow[t]{2}{*}{ Year } & \multirow[t]{2}{*}{ Total Turnovers } & \multicolumn{2}{|c|}{ Successor Origin } & \multicolumn{2}{|c|}{ Departure Type } & \multicolumn{2}{|c|}{ CEO Quality } \\
\hline & & INS & OUT & VOL & FOR & LQY & HQY \\
\hline 1998 & 5 & 3 & 2 & 2 & 3 & 4 & 1 \\
\hline 1999 & 10 & 10 & 0 & 9 & 1 & 8 & 2 \\
\hline 2000 & 13 & 8 & 5 & 12 & 1 & 8 & 5 \\
\hline 2001 & 16 & 8 & 8 & 11 & 5 & 11 & 5 \\
\hline 2002 & 24 & 14 & 10 & 12 & 12 & 21 & 3 \\
\hline 2003 & 17 & 13 & 4 & 10 & 7 & 8 & 9 \\
\hline 2004 & 26 & 16 & 10 & 22 & 4 & 11 & 15 \\
\hline 2005 & 11 & 6 & 5 & 7 & 4 & 6 & 5 \\
\hline 2006 & 25 & 17 & 8 & 20 & 5 & 13 & 12 \\
\hline 2007 & 29 & 22 & 7 & 21 & 8 & 10 & 19 \\
\hline 2008 & 19 & 9 & 10 & 15 & 4 & 8 & 11 \\
\hline 2009 & 13 & 7 & 6 & 7 & 6 & 10 & 3 \\
\hline Total & 208 & 133 & 75 & 148 & 60 & 118 & 90 \\
\hline Total \% & $100 \%$ & $64 \%$ & $36 \%$ & $71 \%$ & $29 \%$ & $57 \%$ & $43 \%$ \\
\hline
\end{tabular}


Table 3: Abnormal Returns

This table reports the mean and median abnormal stock returns obtained from an event study of CEO-turnover announcements. As indicated in column 1 of the table the abnormal returns refer to different event windows. Mean and median abnormal returns are shown in column 2 and column 4, respectively. The table presents results both for the entire sample (Panel A) and for selected subsamples (Panels B-D). The parameters for the market model are estimated over a period of 250 trading days ending 11 days prior the CEO turnover announcement. The one-sided event-study test statistics are the Standardized cross-sectional test by Boehmer, Musumeci, and Poulsen (1991) ( $t$-value) and the Wilcoxon signed rank test ( $z$-value). ***,**, and $*$ denote statistical significance at the $1 \%, 5 \%$, and $10 \%$ confidence level, respectively.

\begin{tabular}{|c|c|c|c|c|}
\hline Days & $\begin{array}{c}\text { Mean } \\
\text { Abnormal Return }\end{array}$ & $t$-Value & $\begin{array}{c}\text { Median } \\
\text { Abnormal Return }\end{array}$ & $z$-Value \\
\hline \multicolumn{5}{|c|}{ Panel A: Total Sample $(\mathrm{N}=208)$} \\
\hline$\left[\begin{array}{ll}-3 & 0\end{array}\right]$ & $0.61 \%$ & 1.1387 & $0.17 \%$ & 1.0540 \\
\hline$\left[\begin{array}{ll}-1 & 0\end{array}\right]$ & $0.48 \%$ & 1.0324 & $-0.01 \%$ & 0.3003 \\
\hline$\left[\begin{array}{ll}-1 & 1\end{array}\right]$ & $0.56 \% *$ & 1.4998 & $0.33 \%$ & 0.7962 \\
\hline-2 & $0.17 \%$ & 0.6078 & $0.07 \%$ & 1.2668 \\
\hline-1 & $0.09 \%$ & -0.2802 & $-0.09 \%$ & 0.6328 \\
\hline $\mathbf{0}$ & $0.39 \% *$ & 1.3533 & $0.02 \%$ & 0.7583 \\
\hline \multicolumn{5}{|c|}{ Panel B: Forced Departure $(\mathrm{N}=60)$} \\
\hline$\left[\begin{array}{ll}-3 & 0\end{array}\right]$ & $2.87 \% * *$ & 1.8488 & $0.25 \%$ ** & 2.0612 \\
\hline$\left[\begin{array}{ll}-1 & 0\end{array}\right]$ & $2.28 \% * *$ & 1.7403 & $0.58 \%$ & 1.2294 \\
\hline$\left[\begin{array}{ll}-1 & 1\end{array}\right]$ & $1.93 \%$ & 1.2356 & $0.33 \%$ & 0.7288 \\
\hline-2 & $0.38 \%$ & 0.0744 & $0.00 \%$ & 0.6994 \\
\hline-1 & $0.57 \%$ & 0.6958 & $-0.05 \%$ & 0.3828 \\
\hline 0 & $1.70 \% *$ & 1.6393 & $0.32 \%$ & 1.2147 \\
\hline \multicolumn{5}{|c|}{ Panel C: Forced Departure of Low-Quality CEOs - H1 $(\mathrm{N}=39)$} \\
\hline$\left[\begin{array}{ll}-3 & 0\end{array}\right]$ & $5.73 \% * * *$ & 3.7868 & $5.03 \% * * *$ & 3.4050 \\
\hline$\left[\begin{array}{ll}-1 & 0\end{array}\right]$ & $4.05 \% * *$ & 2.3431 & $2.34 \% * *$ & 2.0793 \\
\hline$\left[\begin{array}{ll}-1 & 1\end{array}\right]$ & $3.78 \% * *$ & 2.0953 & $2.90 \% *$ & 1.6048 \\
\hline-2 & $0.99 \% *$ & 1.4132 & $0.36 \% *$ & 1.6327 \\
\hline-1 & $1.12 \% *$ & 1.6254 & $0.13 \%$ & 1.2001 \\
\hline 0 & $2.93 \% * *$ & 1.9006 & $1.21 \% * *$ & 1.8839 \\
\hline \multicolumn{5}{|c|}{ Panel D: Forced Departure of High-Quality CEOs - H2 $(\mathrm{N}=21)$} \\
\hline$\left[\begin{array}{ll}-3 & 0\end{array}\right]$ & $-2.44 \% *$ & -1.5566 & $-0.78 \% * *$ & 1.8595 \\
\hline$\left[\begin{array}{ll}-1 & 0\end{array}\right]$ & $-1.01 \%$ & -1.2754 & $-1.51 \% * *$ & 1.6857 \\
\hline$\left[\begin{array}{ll}-1 & 1\end{array}\right]$ & $-1.51 \% *$ & -1.4566 & $-1.22 \% *$ & 1.5120 \\
\hline-2 & $-0.75 \%$ & -1.0054 & $-0.23 \%$ & 1.1644 \\
\hline-1 & $-0.43 \% *$ & -1.3346 & $-0.17 \% *$ & 1.3382 \\
\hline 0 & $-0.58 \%$ & -0.3430 & $-0.08 \%$ & 0.9906 \\
\hline
\end{tabular}


Table 4: Abnormal-Return Ranking for Subsamples

This table shows the abnormal-return rankings for subsamples based on the turnover characteristics successor origin (OUT denotes outside and INS inside successions), departure type (FOR denotes forced and VOL voluntary turnovers), and CEO quality (HQY denotes high- and LQY low-quality CEOs). The subsamples are constructed based on one (Panel A), two (Panel B), and three (Panel C) turnover characteristics. Rank indicates the position of the subsamples with respect to the mean AR in the event window [-3 0] $M e a n$ AR 3 0]). Sample Restriction identifies the sample construction based on one, two, or three sample criteria as listed under $R 1, R 2$, and $R 3$. $N$ indicates the number of CEO turnovers included in each subsample. Finally, $t$-value indicates the test statistics obtained by a one-sided Boehmer test (Boehmer, Musumeci, and Poulsen, 1991). ***, **, and * denote statistical significance at the 1\%, 5\%, and 10\% confidence level, respectively.

\begin{tabular}{|c|c|c|c|c|c|c|}
\hline \multirow[t]{2}{*}{ Rank } & \multicolumn{3}{|c|}{ Sample Restriction } & \multirow[t]{2}{*}{$\mathbf{N}$} & \multirow{2}{*}{$\begin{array}{c}\text { Mean } \\
\text { AR }\left[\begin{array}{ll}-3 & 0\end{array}\right]\end{array}$} & \multirow[t]{2}{*}{ t-Value } \\
\hline & R1 & R2 & R3 & & & \\
\hline \multicolumn{7}{|c|}{ Panel A: Restriction on One Turnover Characteristics } \\
\hline 1 & FOR & - & - & 60 & $2.87 \% * *$ & 1.8488 \\
\hline 2 & LQY & - & - & 118 & $2.07 \% * * *$ & 3.4958 \\
\hline 3 & OUT & - & - & 75 & $1.76 \% * *$ & 2.0340 \\
\hline 4 & INS & - & - & 133 & $-0.04 \%$ & 0.1792 \\
\hline 5 & VOL & - & - & 148 & $-0.31 \%$ & -0.0772 \\
\hline 6 & HQY & - & - & 90 & $-1.30 \% * *$ & -1.8043 \\
\hline \multicolumn{7}{|c|}{ Panel B: Restriction on Two Turnover Characteristics } \\
\hline 1 & OUT & FOR & - & 21 & $6.57 \%$ *** & 2.5692 \\
\hline 2 & FOR & LQY & - & 39 & $5.73 \% * * *$ & 3.7868 \\
\hline 3 & OUT & LQY & - & 42 & $3.80 \% * * *$ & 2.8765 \\
\hline 4 & INS & LQY & - & 76 & $1.10 \% * *$ & 2.2874 \\
\hline 5 & INS & FOR & - & 39 & $0.88 \%$ & 0.8352 \\
\hline 6 & VOL & LQY & - & 79 & $0.25 \% *$ & 1.3326 \\
\hline 7 & OUT & VOL & - & 54 & $-0.10 \%$ & 0.7120 \\
\hline 8 & INS & VOL & - & 94 & $-0.43 \%$ & -0.5112 \\
\hline 9 & OUT & HQY & - & 33 & $-0.83 \%$ & -0.3372 \\
\hline 10 & VOL & HQY & - & 69 & $-0.95 \%$ & -1.1528 \\
\hline 11 & INS & HQY & - & 57 & $-1.57 \% * *$ & -1.8316 \\
\hline 12 & FOR & HQY & - & 21 & $-2.44 \% *$ & -1.5566 \\
\hline \multicolumn{7}{|c|}{ Panel C: Restriction on Three Turnover Characteristics } \\
\hline 1 & LQY & FOR & OUT & 14 & $10.58 \% * * *$ & 4.4161 \\
\hline 2 & LQY & FOR & INS & 25 & $3.02 \% * *$ & 2.1522 \\
\hline 3 & LQY & VOL & OUT & 28 & $0.41 \%$ & 0.7881 \\
\hline 4 & LQY & VOL & INS & 51 & $0.17 \%$ & 1.0639 \\
\hline 5 & HQY & VOL & OUT & 26 & $-0.66 \%$ & 0.1990 \\
\hline 6 & HQY & VOL & INS & 43 & $-1.13 \% *$ & -1.4027 \\
\hline 7 & HQY & FOR & OUT & 7 & $-1.46 \% *$ & -1.8437 \\
\hline 8 & HQY & FOR & INS & 14 & $-2.94 \%$ & -1.1631 \\
\hline
\end{tabular}


Table 5: Cross-Sectional Regressions of Abnormal Returns

This table reports the results of regressing the [-3 0$]$-abnormal returns on a set of explanatory variables. The sample consists of 208 CEO turnovers over the time period between December 1998 and June 2009. Outside successions and forced departures are denoted by OUT and FOR, respectively. HQY is a dummy variable that indicates a high-quality CEO. The variable assumes a value of one if the company outperformed the market in the year preceding the turnover. SIZE denotes the logarithm of total assets, AGEDEP the age of the departing CEO and AGEINC of the appointed CEO. DUALOLD assumes a value of one if the CEO turnover ends a dual-mandate structure and zero otherwise. DUALNEW assumes a value of one if the CEO turnover introduces a dual-mandate structure and zero otherwise. FOR $*$ HQY is a dummy variable denoting forced turnovers of high-quality CEOs. ***, **, and * denote statistical significance at the $1 \%, 5 \%$, and $10 \%$ confidence level, respectively, and the corresponding $t$-values are depicted in parentheses.

\begin{tabular}{|c|c|c|c|c|c|c|}
\hline & (1) & $(2)$ & $(3)$ & $(4)$ & $(5)$ & $(6)$ \\
\hline \multirow[t]{2}{*}{ CONST } & -0.0004 & -0.0031 & $0.0207^{* * *}$ & 0.0316 & 0.0045 & -0.0043 \\
\hline & $(-0.0780)$ & $(-0.5917)$ & $(3.5533)$ & $(0.1897)$ & $(0.6291)$ & $(-0.5590)$ \\
\hline \multirow[t]{2}{*}{ OUT } & $0.0181^{* *}$ & & & $0.0185^{* *}$ & $0.0188^{* *}$ & $0.0198^{* *}$ \\
\hline & $(1.9345)$ & & & $(2.0846)$ & $(2.1200)$ & $(2.2756)$ \\
\hline \multirow[t]{2}{*}{ FOR } & & $0.0318^{* * *}$ & & $0.0524^{* * *}$ & $0.0285^{* * *}$ & $0.0491 * * *$ \\
\hline & & $(3.2648)$ & & $(4.0341)$ & $(3.0118)$ & $(4.0195)$ \\
\hline \multirow[t]{2}{*}{ HQY } & & & $-0.0337^{* * *}$ & $-0.0133^{*}$ & $-0.0311^{* * *}$ & $-0.0129^{*}$ \\
\hline & & & $(-3.8108)$ & $(-1.3286)$ & $(-3.5958)$ & $(-1.3150)$ \\
\hline \multirow[t]{2}{*}{ SIZE } & & & & -0.0014 & & \\
\hline & & & & $(-0.7755)$ & & \\
\hline \multirow[t]{2}{*}{ AGEDEP } & & & & 0.0129 & & \\
\hline & & & & $(0.3972)$ & & \\
\hline \multirow[t]{2}{*}{ AGEINC } & & & & -0.0175 & & \\
\hline & & & & $(-0.5660)$ & & \\
\hline \multirow[t]{2}{*}{ DUALOLD } & & & & -0.0054 & & -0.0053 \\
\hline & & & & $(-0.3552)$ & & $(0.6236)$ \\
\hline \multirow[t]{2}{*}{ DUALNEW } & & & & $0.0321^{*}$ & & $0.0303^{*}$ \\
\hline & & & & $(1.6134)$ & & $(1.5587)$ \\
\hline \multirow[t]{2}{*}{$\mathrm{FOR}^{*} \mathrm{HQY}$} & & & & $-0.0650 * * *$ & & $-0.0643^{* * *}$ \\
\hline & & & & $(-3.3593)$ & & $(-3.3653)$ \\
\hline adj. $R^{2}$ & 0.0131 & 0.0446 & 0.0613 & 0.1552 & 0.1105 & 0.1633 \\
\hline
\end{tabular}


Table 6: Cross-Sectional Regressions for Forced Turnovers

This table reports the results of regressing the abnormal returns of forced turnovers from the period [ -3 0] on a set of explanatory variables. The sample consists of 60 forced CEO turnovers in the time period between 1998 and 2009 . OUT denotes outside successions. QY denotes prior stock performance relative to the market. SIZE denotes the logarithm of total assets, AGEDEP the age of the departing CEO and AGEINC of the appointed CEO. DUALOLD assumes a value of one if the CEO turnover ends a dual-mandate structure and zero otherwise. DUALNEW assumes a value of one if the CEO turnover introduces a dual-mandate structure and zero otherwise. ***, **, and $*$ denote statistical significance at the 1\%, $5 \%$, and $10 \%$ confidence level, respectively, and the corresponding $t$-values are depicted in parentheses.

\begin{tabular}{|c|c|c|c|c|c|}
\hline & (1) & $(2)$ & (3) & (4) & $(5)$ \\
\hline \multirow[t]{2}{*}{ CONST } & 0.0088 & 0.0020 & 0.1245 & -0.0085 & $-0.0160^{*}$ \\
\hline & $(0.6519)$ & $(0.1908)$ & $(0.3188)$ & $(-0.7354)$ & $(-1.3059)$ \\
\hline \multirow[t]{2}{*}{ OUT } & $0.0569 * * *$ & & $0.0429 * *$ & $0.0351^{* *}$ & $0.0416^{* *}$ \\
\hline & $(2.4898)$ & & $(2.1028)$ & $(1.8232)$ & $(2.1532)$ \\
\hline \multirow[t]{2}{*}{ QY } & & $-0.0841^{* * *}$ & $-0.0756^{* * *}$ & $-0.0785^{* * *}$ & $-0.0760^{* * *}$ \\
\hline & & $(-5.7634)$ & $(-5.0353)$ & $(-5.3583)$ & $(-5.2467)$ \\
\hline \multirow[t]{2}{*}{ SIZE } & & & 0.0016 & & \\
\hline & & & $(0.4880)$ & & \\
\hline \multirow[t]{2}{*}{ AGEDEP } & & & -0.0246 & & \\
\hline & & & $(-0.3197)$ & & \\
\hline \multirow[t]{2}{*}{ AGEINC } & & & -0.0175 & & \\
\hline & & & $(-0.2817)$ & & \\
\hline \multirow[t]{2}{*}{ DUALNEW } & & & $0.0461^{*}$ & & $0.0446 * *$ \\
\hline & & & $(1.6614)$ & & $(1.6792)$ \\
\hline adj. $R^{2}$ & 0.0810 & 0.3532 & 0.3678 & 0.3781 & 0.3973 \\
\hline
\end{tabular}


Table 7: Rejection Rates for Different Event-Study Tests

This table shows the empirical rejection rates for the Bootstrap, the Standardized cross-sectional (Boehmer, Musumeci, and Poulsen, 1991), and the Wilcoxon signed rank test when there is no abnormal return present in the data. The underlying sample for this historical simulation includes all SPI companies in the period from January 1990 to June 2009. This initial sample is employed to generate 250 random samples by choosing each time randomly a number of securities, $N(N \in\{10 ; 20 ; 50 ; 100\})$ with replacement. The Bootstrap test was conducted by resampling 10,000 times from our initial sample of abnormal returns. The rejection rates of the simulations are obtained in a two-tailed test.

\begin{tabular}{|c|c|c|c|c|c|}
\hline \multirow[t]{2}{*}{ Method } & \multicolumn{5}{|c|}{ Number of Events } \\
\hline & 10 & 20 & 50 & 100 & 200 \\
\hline \multicolumn{6}{|c|}{ Panel A: Significance Level 10\% } \\
\hline Bootstrap & $10.80 \%$ & $9.60 \%$ & $10.00 \%$ & $10.00 \%$ & $11.60 \%$ \\
\hline Boehmer & $7.60 \%$ & $8.00 \%$ & $10.80 \%$ & $8.40 \%$ & $12.00 \%$ \\
\hline Wilcoxon & $8.80 \%$ & $9.20 \%$ & $10.00 \%$ & $9.20 \%$ & $15.20 \%$ \\
\hline \multicolumn{6}{|c|}{ Panel B: Significance Level 5\% } \\
\hline$\overline{\text { Bootstrap }}$ & $6.40 \%$ & $6.00 \%$ & $4.00 \%$ & $5.60 \%$ & $6.80 \%$ \\
\hline Boehmer & $5.20 \%$ & $5.20 \%$ & $4.80 \%$ & $4.80 \%$ & $7.20 \%$ \\
\hline Wilcoxon & $2.00 \%$ & $5.60 \%$ & $6.00 \%$ & $4.80 \%$ & $4.80 \%$ \\
\hline \multicolumn{6}{|c|}{ Panel C: Significance Level 1\% } \\
\hline Bootstrap & $1.60 \%$ & $1.60 \%$ & $1.60 \%$ & $1.20 \%$ & $1.60 \%$ \\
\hline Boehmer & $0.00 \%$ & $0.80 \%$ & $1.20 \%$ & $0.80 \%$ & $1.60 \%$ \\
\hline Wilcoxon & $0.00 \%$ & $0.00 \%$ & $0.80 \%$ & $0.40 \%$ & $1.60 \%$ \\
\hline
\end{tabular}


Table 8: Robustness of Abnormal Returns

This table shows the significance of nine event-study tests for abnormal stock returns. The test statistics are the Traditional and the Portfolio test (Brown and Warner, 1980), the Standardized-residual test (Patell, 1976), the Ruback (1982) test, the Standardized cross-sectional test (Boehmer, Musumeci, and Poulsen, 1991), a Bootstrap test, the Corrado (1989) rank test, the Generalized rank test (Kolari and Pynnonen, 2008) and the Wilcoxon signed rank test Wilcoxon (1945). All results refer to one-sided tests. ${ }^{* *}, * *$, and $*$ denote statistical significance at the $1 \%, 5 \%$, and $10 \%$ confidence level, respectively.

\begin{tabular}{|c|c|c|c|c|c|c|c|c|c|}
\hline Days & Traditional & Portfolio & Patell & Ruback & Boehmer & Bootstrap & Corrado Rank & Gen. Rank & Wilcoxon \\
\hline \multicolumn{10}{|c|}{ Panel A: Total Sample $(\mathrm{N}=208)$} \\
\hline$\left[\begin{array}{ll}-3 & 0\end{array}\right]$ & $1.5110^{*}$ & $1.5123^{*}$ & $1.7018^{* *}$ & $1.5903^{*}$ & 1.1387 & $1.3349^{*}$ & 1.1784 & $1.4608^{*}$ & 1.0540 \\
\hline$\left[\begin{array}{ll}-2 & 0\end{array}\right]$ & $1.8642^{* *}$ & $1.8657^{* *}$ & $1.9079 * *$ & $1.9505^{* *}$ & 1.1578 & $1.4542^{*}$ & 1.2050 & $1.5761^{*}$ & 1.1679 \\
\hline$\left[\begin{array}{ll}-1 & 1\end{array}\right]$ & $1.6102^{*}$ & $1.6115^{*}$ & $2.5316^{* * *}$ & $1.6847^{* *}$ & $1.4998^{*}$ & 1.1566 & 1.2431 & $1.5643^{*}$ & 0.7962 \\
\hline-1 & 0.4332 & 0.4335 & -0.3368 & 0.4335 & -0.2802 & 0.3873 & -0.5469 & -0.4532 & 0.6328 \\
\hline 0 & $1.9282^{* *}$ & $1.9298^{* *}$ & $2.9139^{* * *}$ & $1.9298^{* *}$ & $1.3533^{*}$ & 1.1070 & $1.3964^{*}$ & $1.4749^{*}$ & 0.7583 \\
\hline 1 & 0.4275 & 0.4279 & $1.8257^{* *}$ & 0.4279 & $1.3964^{*}$ & 0.3733 & $1.3036^{*}$ & $1.3829^{*}$ & 0.6651 \\
\hline \multicolumn{10}{|c|}{ Panel B: Forced Departure $(\mathrm{N}=60)$} \\
\hline$\left[\begin{array}{ll}-3 & 0\end{array}\right]$ & $3.1343^{* * *}$ & $3.2192^{* * *}$ & $3.3307^{* * *}$ & $3.2101^{* * *}$ & $1.8488^{* *}$ & $2.5427^{* * *}$ & $1.7135^{* *}$ & $2.3262^{* *}$ & $2.0612^{* *}$ \\
\hline$\left[\begin{array}{ll}-2 & 0\end{array}\right]$ & $3.3488^{* * *}$ & $3.4395^{* * *}$ & $3.1122^{* * *}$ & $3.4308^{* * *}$ & $1.5253^{*}$ & $2.2672^{* *}$ & $1.4308^{*}$ & $2.1035^{* *}$ & $1.7153^{* *}$ \\
\hline$\left[\begin{array}{ll}-1 & 1\end{array}\right]$ & $2.4273^{* * *}$ & $2.4930 * * *$ & $2.6129^{* * *}$ & $2.4867^{* * *}$ & 1.2356 & $1.3077^{*}$ & 0.7114 & 1.0772 & 0.7288 \\
\hline-1 & 1.2521 & 1.2860 & 0.9460 & 1.2860 & 0.6958 & 1.0205 & 0.4701 & 0.5193 & 0.3828 \\
\hline 0 & $3.7204^{* * *}$ & $3.8212^{* * *}$ & $4.3514^{* * *}$ & $3.8212^{* * *}$ & $1.6393^{*}$ & $1.6933^{* *}$ & $1.5433^{*}$ & $1.5870^{*}$ & 1.2147 \\
\hline 1 & -0.7683 & -0.7891 & -0.7534 & -0.7891 & -0.5120 & -0.5074 & -0.7812 & -0.7256 & 0.7877 \\
\hline \multicolumn{10}{|c|}{ Panel C: Forced Departure of Low-Quality CEOs - H1 (N = 39) } \\
\hline$\left[\begin{array}{ll}-3 & 0\end{array}\right]$ & $4.3710^{* * *}$ & $4.4429^{* * *}$ & $6.1012^{* * *}$ & $4.4925^{* * *}$ & $3.7868^{* * *}$ & $4.1047^{* * *}$ & $3.8432^{* * *}$ & $4.0071^{* * *}$ & $3.4050^{* * *}$ \\
\hline$\left[\begin{array}{ll}-2 & 0\end{array}\right]$ & $4.4321^{* * *}$ & $4.5050^{* * *}$ & $5.5948^{* * *}$ & $4.5496^{* * *}$ & $2.7606^{* * *}$ & $3.2470^{* * *}$ & $2.9221^{* * *}$ & $3.0426 * * *$ & $2.7491^{* * *}$ \\
\hline$\left[\begin{array}{ll}-1 & 1\end{array}\right]$ & $3.3258^{* * *}$ & $3.3805^{* * *}$ & $4.8074^{* * *}$ & $3.4139 * * *$ & $2.0953^{* *}$ & $1.8165^{* *}$ & $2.0575^{* *}$ & $1.8261^{* *}$ & $1.6048^{*}$ \\
\hline-1 & $1.6997^{* *}$ & $1.7276^{* *}$ & $2.2981^{* *}$ & $1.7276^{* *}$ & $1.6254^{*}$ & $1.3526^{*}$ & $1.3905^{*}$ & $1.4252^{*}$ & 1.2001 \\
\hline 0 & $4.4710^{* * *}$ & $4.5446^{* * *}$ & $5.7886^{* * *}$ & $4.5446^{* * *}$ & $1.9006^{* *}$ & $1.9974^{* *}$ & $2.1657^{* *}$ & $2.1968 * *$ & $1.8839^{* *}$ \\
\hline 1 & -0.4103 & -0.4171 & 0.2737 & -0.4171 & 0.1737 & -0.2339 & 0.0074 & 0.0485 & 0.3628 \\
\hline \multicolumn{10}{|c|}{ Panel D: Forced Departure of High-Quality CEOs $-\mathrm{H} 2(\mathrm{~N}=21)$} \\
\hline$\left[\begin{array}{ll}-3 & 0\end{array}\right]$ & $-2.5461^{* * *}$ & $-2.6194^{* * *}$ & $-2.6847^{* * *}$ & $-2.6276^{* * *}$ & $-1.5566^{*}$ & $-1.9568^{* *}$ & $-2.3167^{* *}$ & $-1.3907^{*}$ & $1.8595^{* *}$ \\
\hline$\left[\begin{array}{ll}-2 & 0\end{array}\right]$ & $-2.1157^{* *}$ & $-2.1766^{* *}$ & $-2.3638^{* *}$ & $-2.1827 * *$ & $-1.3387^{*}$ & $-1.6367^{*}$ & $-1.5529^{*}$ & -0.7838 & $1.3729^{*}$ \\
\hline$\left[\begin{array}{ll}-1 & 1\end{array}\right]$ & $-1.8213^{* *}$ & $-1.8737^{* *}$ & $-2.1347 * *$ & $-1.8789^{* *}$ & $-1.4566^{*}$ & $-1.7882^{* *}$ & $-1.5757^{*}$ & -1.0560 & $1.5120^{*}$ \\
\hline-1 & -0.8993 & -0.9251 & $-1.5327^{*}$ & -0.9251 & $-1.3346^{*}$ & -0.8885 & -1.0824 & -1.0484 & $1.3382^{*}$ \\
\hline 0 & -1.2004 & -1.2349 & -0.5332 & -1.2349 & -0.3430 & -0.9789 & -0.3645 & -0.3336 & 0.9906 \\
\hline 1 & -1.0549 & -1.0853 & $-1.6465^{*}$ & -1.0853 & -1.3177 & -1.0958 & $-1.2822^{*}$ & -1.2474 & 1.0949 \\
\hline
\end{tabular}


Table 9: Cross-Sectional Regressions for Sub-Periods

This table reports the results of regressing the $\left[\begin{array}{ll}-3 & 0\end{array}\right]$-abnormal returns on a set of variables. The total sample as well as the sample of forced turnovers is split in two sub-periods. The first sub-period starts in 1998 and ends in 2003 and the second sub-period lasts from 2004 to 2009. Outside successions and forced departures are denoted by OUT and FOR, respectively. QY denotes prior stock performance relative to the market. HQY is a dummy variable that indicates a high-quality CEO. The variable assumes a value of one if the company outperformed the market in the year preceding the turnover. SIZE denotes the logarithm of total assets, AGEDEP the age of the departing CEO and AGEINC of the appointed CEO. DUALOLD assumes a value of one if the CEO turnover ends a dual-mandate structure and zero otherwise. DUALNEW assumes a value of one if the CEO turnover introduces a dual-mandate structure and zero otherwise. FOR ${ }^{*} \mathrm{HQY}$ is a dummy variable denoting forced turnovers of high-quality CEOs. ***, **, and * denote statistical significance at the $1 \%, 5 \%$, and $10 \%$ confidence level, respectively, and the corresponding $t$-values are depicted in parentheses.

\begin{tabular}{|c|c|c|c|c|}
\hline & \multicolumn{2}{|c|}{ All Turnovers } & \multicolumn{2}{|c|}{ Forced Turnovers } \\
\hline & $(1)$ & $(2)$ & $(3)$ & $(4)$ \\
\hline & $1998-2003$ & 2004-2009 & $1998-2003$ & 2004-2009 \\
\hline & $(\mathrm{N}=85)$ & $(\mathrm{N}=123)$ & $(\mathrm{N}=31)$ & $(\mathrm{N}=29)$ \\
\hline \multirow[t]{2}{*}{ CONST } & -0.0114 & 0.0010 & -0.0110 & -0.0206 \\
\hline & $(-0.9650)$ & $(0.0985)$ & $(-0.5768)$ & $(-1.2251)$ \\
\hline \multirow[t]{2}{*}{ OUT } & $0.0283^{* *}$ & $0.0158^{*}$ & 0.0339 & $0.0497^{* *}$ \\
\hline & $(1.8386)$ & $(1.5351)$ & $(1.0825)$ & $(1.8973)$ \\
\hline \multirow[t]{2}{*}{ FOR } & $0.0660 * * *$ & $0.0284^{* *}$ & & \\
\hline & $(3.5687)$ & $(1.7247)$ & & \\
\hline \multirow[t]{2}{*}{ QY } & & & $-0.0755^{* * *}$ & $-0.0744^{* *}$ \\
\hline & & & $(-3.9867)$ & $(-2.3166)$ \\
\hline \multirow[t]{2}{*}{ HQY } & -0.0016 & $-0.0180^{*}$ & & \\
\hline & $(-0.0805)$ & $(-1.5631)$ & & \\
\hline \multirow[t]{2}{*}{ DUALOLD } & -0.0410 & 0.0053 & & \\
\hline & $(-0.1254)$ & $(1.1294)$ & & \\
\hline \multirow[t]{2}{*}{ DUALNEW } & $0.0568^{*}$ & 0.0202 & 0.0485 & 0.0428 \\
\hline & $(1.5929)$ & $(0.8962)$ & $(1.0153)$ & $(1.2803)$ \\
\hline \multirow[t]{2}{*}{ FOR*HQY } & $-0.0974^{* * *}$ & $-0.0365^{*}$ & & \\
\hline & $(-2.8543)$ & $(-1.5657)$ & & \\
\hline adj. $R^{2}$ & 0.2337 & 0.0793 & 0.4253 & 0.2353 \\
\hline
\end{tabular}


Table 10: Cross-Sectional Regression for Forced Turnovers with Different Performance Periods

This table reports the results of regressing the [-3 0$]$-abnormal returns of forced CEO turnovers on a set of variables. Outside successions and forced departures are denoted by OUT and FOR, respectively. QY denotes prior stock performance relative to the market measured over different time periods, i.e. 50, 125, 250 (standard estimation period), 375, and 500 days. SIZE denotes the logarithm of total assets, AGEDEP the age of the departing CEO and AGEINC of the appointed CEO. DUALNEW assumes a value of one if the CEO turnover introduces a dual-mandate structure and zero otherwise. The differing number of CEO turnovers is due to the restriction of at least $40 \%$ trading days in the estimation window for the market model and the availablity of a time series of up to 500 days of returns. $* * *, * *$, and $*$ denote statistical significance at the $1 \%, 5 \%$, and $10 \%$ confidence level, respectively, and the corresponding $t$-values are depicted in parentheses.

\begin{tabular}{cccccc}
\hline & $(1)$ & $(2)$ & $(3)$ & $(4)$ & $(5)$ \\
& 50 days & 125 days & 250 days & 375 days & 500 days \\
& $(\mathrm{N}=59)$ & $(\mathrm{N}=58)$ & $(\mathrm{N}=60)$ & $(\mathrm{N}=59)$ & $(\mathrm{N}=57)$ \\
\hline CONST & 0.0276 & -0.018 & 0.1245 & 0.0799 & -0.0177 \\
OUT & $(0.0663)$ & $(-0.0445)$ & $(0.3188)$ & $(0.1871)$ & $(-0.0411)$ \\
& $0.0481^{* *}$ & $0.0446^{* *}$ & $0.0429^{* *}$ & $0.0469^{* *}$ & $0.047^{* *}$ \\
QY & $(2.153)$ & $(2.0242)$ & $(2.1028)$ & $(2.0798)$ & $(2.0782)$ \\
& $-0.1842^{* * *}$ & $-0.0879^{* * *}$ & $-0.0756^{* * *}$ & $-0.0465^{* * *}$ & $-0.0489^{* * *}$ \\
SIZE & $(-4.3257)$ & $(-4.1397)$ & $(-5.0353)$ & $(-3.4235)$ & $(-3.4212)$ \\
& 0.0005 & 0.0014 & 0.0016 & 0.0011 & 0.0015 \\
AGEDEP & $(0.1415)$ & $(0.3932)$ & $(0.488)$ & $(0.3097)$ & $(0.4169)$ \\
& 0.0211 & 0.016 & -0.0246 & -0.0165 & 0.0139 \\
AGEINC & $(0.2549)$ & $(0.1997)$ & $(-0.3197)$ & $(-0.1957)$ & $(0.1613)$ \\
& -0.0323 & -0.0196 & -0.0175 & -0.0117 & -0.0195 \\
DUALNEW & $(-0.4748)$ & $(-0.3015)$ & $(-0.2817)$ & $(-0.175)$ & $(-0.2909)$ \\
& $0.0637^{* *}$ & $0.062^{* *}$ & $0.0461^{*}$ & $0.0517^{* *}$ & $0.0479 *$ \\
adj. $R^{2}$ & $(2.1449)$ & $(2.1662)$ & $(1.6614)$ & $(1.7259)$ & $(1.5103)$ \\
\hline
\end{tabular}


Table 11: Cross-Sectional Regression for Forced Turnovers with Industry-Adjusted Performance

This table reports the results of regressing the abnormal returns of forced turnovers from the period $[-30]$ on a set of explanatory variables. The sample consists of 60 forced CEO turnovers in the time period between 1998 and 2009. OUT denotes outside successions. QYIA denotes prior stock performance relative to the corresponding industry index. SIZE denotes the logarithm of total assets, AGEDEP the age of the departing CEO and AGEINC of the appointed CEO. DUALNEW assumes a value of one if the CEO turnover introduces a dual-mandate structure and zero otherwise. DUALOLD is not used in this regression because there was no forced departure of a CEO holding also the position as a director of the board. ***, **, and $*$ denote statistical significance at the $1 \%, 5 \%$, and $10 \%$ confidence level, respectively, and the corresponding $t$-values are depicted in parentheses.

\begin{tabular}{ccccc}
\hline & $(1)$ & $(2)$ & $(3)$ & $(4)$ \\
\hline CONST & 0.0101 & 0.0096 & -0.0030 & -0.0117 \\
OUT & $(0.9234)$ & $(0.9219)$ & $(-0.2492)$ & $(-0.9251)$ \\
& & $0.0487^{* *}$ & $0.0479^{* *}$ & $0.0471^{* *}$ \\
QYIA & $(2.2026)$ & $(2.2675)$ & $(2.3478)$ \\
& $-0.0810^{* * *}$ & $-0.0726^{* * *}$ & $-0.0749^{* * *}$ & $-0.0730^{* * *}$ \\
SIZE & $(-4.8838)$ & $(-4.3461)$ & $(-4.5541)$ & $(-4.5160)$ \\
& & 0.0018 & & \\
AGEDEP & $(0.5118)$ & & \\
AGEINC & -0.0318 & & \\
& & $(-0.3963)$ & & $0.0504^{* *}$ \\
DUALNEW & -0.0279 & & $(1.8200)$ \\
\hline adj. $R^{2}$ & & $(-0.4307)$ & & 0.3411 \\
\hline
\end{tabular}


Table 12: Changes in Operating Performance

This table shows mean and median changes in operating performance for different subsamples and event windows. $* * *, * *$, and $*$ denote significance at the $1 \%, 5 \%$, and $10 \%$ confidence level, respectively, for two-tailed tests.

\begin{tabular}{|c|c|c|c|c|c|}
\hline Years & $\mathbf{N}$ & $\begin{array}{c}\text { Mean } \\
\text { OROA Change }\end{array}$ & $t$-Value & $\begin{array}{c}\text { Median } \\
\text { OROA Change }\end{array}$ & $z$-Value \\
\hline \multicolumn{6}{|c|}{ Panel A: Total Sample } \\
\hline$\left[\begin{array}{ll}-2 & 0\end{array}\right]$ & 196 & $-2.45 \% * * *$ & -2.7789 & $-0.38 \% * * *$ & 3.4660 \\
\hline$\left[\begin{array}{ll}-1 & 0\end{array}\right]$ & 201 & $-2.65 \% *$ & -1.8763 & $-0.22 \% * * *$ & 2.7147 \\
\hline$\left[\begin{array}{ll}0 & 1\end{array}\right]$ & 185 & $2.62 \%$ & 0.6184 & $0.30 \%$ & 0.5231 \\
\hline$\left[\begin{array}{ll}0 & 2\end{array}\right]$ & 162 & $3.40 \% * * *$ & 2.6476 & $0.36 \% * *$ & 2.0293 \\
\hline \multicolumn{6}{|c|}{ Panel B: Forced Departures } \\
\hline$\left[\begin{array}{ll}-2 & 0\end{array}\right]$ & 57 & $-5.40 \% *$ & -1.9826 & $-0.63 \% * * *$ & 3.9289 \\
\hline$\left[\begin{array}{ll}-1 & 0\end{array}\right]$ & 59 & $-3.80 \%$ & -1.3375 & $-0.46 \% *$ & 1.7436 \\
\hline$\left[\begin{array}{ll}0 & 1\end{array}\right]$ & 51 & $4.36 \%$ & 0.5596 & $0.59 \%$ & 0.0281 \\
\hline$\left[\begin{array}{ll}0 & 2\end{array}\right]$ & 46 & $5.61 \%$ & 1.4054 & $0.91 \%$ & 1.3384 \\
\hline \multicolumn{6}{|c|}{ Panel C: Forced Departure of Low-Quality CEOs } \\
\hline$\left[\begin{array}{ll}-2 & 0\end{array}\right]$ & 37 & $-8.07 \% *$ & -1.9414 & $-1.14 \% * * *$ & 4.0205 \\
\hline$\left[\begin{array}{ll}-1 & 0\end{array}\right]$ & 38 & $-5.74 \%$ & -1.3313 & $-0.82 \% * *$ & 2.2406 \\
\hline$\left[\begin{array}{ll}0 & 1\end{array}\right]$ & 33 & $7.37 \%$ & 1.4746 & $1.10 \%$ & 0.9917 \\
\hline$\left[\begin{array}{ll}0 & 2\end{array}\right]$ & 29 & $8.82 \% * *$ & 2.2932 & $2.13 \% * *$ & 2.3461 \\
\hline \multicolumn{6}{|c|}{ Panel D: Forced Departure of High-Quality CEOs } \\
\hline$\left[\begin{array}{ll}-2 & 0\end{array}\right]$ & 20 & $-0.45 \%$ & -0.5900 & $0.41 \%$ & 1.1573 \\
\hline$\left[\begin{array}{ll}-1 & 0\end{array}\right]$ & 21 & $-0.15 \%$ & -0.1646 & $0.26 \%$ & 0.3302 \\
\hline$\left[\begin{array}{ll}0 & 1\end{array}\right]$ & 18 & $-1.23 \% *$ & -1.7790 & $-0.53 \%$ & 1.5025 \\
\hline$\left[\begin{array}{ll}0 & 2\end{array}\right]$ & 17 & $-0.27 \%$ & -0.9792 & $-0.71 \%$ & 1.0651 \\
\hline
\end{tabular}


Table 13: Cross-Sectional Regressions of Operating Performance

This table shows the results of regressing OROAs adjusted with (i) the lagged OROA (LA-OROA, Regressions 1 and 2), (ii) the median industry OROA (IA-OROA, Regressions 3 and 4), and (iii) the lagged OROA and median OROA Change (LIA-OROA, Regressions 5 and 6) on a set of explanatory variables and controls. Outside successions and forced departures are denoted by OUT and FOR, respectively. HQY is a dummy variable that indicates a high-quality CEO. The variable assumes a value of one if the company outperformed the market in the year preceding the turnover. SIZE denotes the logarithm of total assets, AGEDEP the age of the departing CEO and AGEINC of the appointed CEO. DUALOLD assumes a value of one if the CEO turnover ends a dual-mandate structure and zero otherwise. DUALNEW assumes a value of one if the CEO turnover introduces a dual-mandate structure and zero otherwise. FOR*HQY is a dummy variable denoting forced turnovers of high-quality CEOs. ${ }^{* * *},{ }^{* *}$, and ${ }^{*}$ denote statistical significance at the $1 \%, 5 \%$, and $10 \%$ confidence level, respectively, in a two-tailed test and $t$-values are depicted in parentheses.

\begin{tabular}{|c|c|c|c|c|c|c|}
\hline \multirow[t]{2}{*}{ Dependent Variable } & \multicolumn{2}{|c|}{ LA-OROA } & \multicolumn{2}{|c|}{ IA-OROA } & \multicolumn{2}{|c|}{ LIA-OROA } \\
\hline & (1) & $(2)$ & $(3)$ & $(4)$ & $(5)$ & $(6)$ \\
\hline \multirow[t]{2}{*}{ CONST } & 0.2117 & -0.0105 & 0.1157 & $-0.0213^{* *}$ & 0.1521 & -0.0164 \\
\hline & -0.6067 & $(-0.6936)$ & $(0.4767)$ & $(-2.0127)$ & $(0.425)$ & $(-1.0539)$ \\
\hline \multirow[t]{2}{*}{ OUT } & -0.007 & -0.0028 & -0.0104 & -0.0113 & -0.0113 & -0.0072 \\
\hline & $(-0.3774)$ & $(-0.1578)$ & $(-0.8136)$ & $(-0.9166)$ & $(-0.5965)$ & $(-0.3963)$ \\
\hline \multirow[t]{2}{*}{ FOR } & 0.0437 & 0.0332 & 0.0271 & $0.0299^{*}$ & $0.0523^{*}$ & $0.0443^{*}$ \\
\hline & $(1.5828)$ & $(1.3516)$ & $(1.4151)$ & $(1.7478)$ & $(1.8451)$ & $(1.7636)$ \\
\hline \multirow[t]{2}{*}{ HQY } & 0.0317 & $0.0341^{*}$ & $0.0432^{* * *}$ & $0.0451^{* * *}$ & $0.0492^{* *}$ & $0.0508^{* *}$ \\
\hline & $(1.5433)$ & $(1.6971)$ & $(3.0407)$ & $(3.2376)$ & $(2.3356)$ & $(2.472)$ \\
\hline \multirow[t]{2}{*}{ SIZE } & -0.0014 & & 0.001 & & -0.0012 & \\
\hline & $(-0.3636)$ & & $(0.3669)$ & & $(-0.2951)$ & \\
\hline \multirow[t]{2}{*}{ AGEDEP } & 0.0163 & & 0.0181 & & 0.0112 & \\
\hline & $(0.2374)$ & & $(0.3802)$ & & $(0.1593)$ & \\
\hline \multirow[t]{2}{*}{ AGEINC } & -0.0685 & & -0.0582 & & -0.0498 & \\
\hline & $(-1.0554)$ & & $(-1.2971)$ & & $(-0.7485)$ & \\
\hline \multirow[t]{2}{*}{ DUALOLD } & 0.0007 & & 0.0003 & & -0.0117 & \\
\hline & $(0.0234)$ & & $(0.0151)$ & & $(-0.3781)$ & \\
\hline \multirow[t]{2}{*}{ DUALNEW } & -0.0198 & & 0.041 & & -0.0239 & \\
\hline & $(-0.4495)$ & & $(1.4206)$ & & $(-0.5293)$ & \\
\hline \multirow[t]{2}{*}{ FOR*HQY } & $-0.0820 * *$ & $-0.0783^{* *}$ & $-0.0579 * *$ & $-0.0676^{* *}$ & $-0.0996 * *$ & $-0.0948 * *$ \\
\hline & $(-1.9861)$ & $(-1.9854)$ & $(-2.0194)$ & $(-2.4540)$ & $(-2.3524)$ & $(-2.3457)$ \\
\hline
\end{tabular}


Figure 1: Abnormal Trading Volume

The following graphs show the standardized mean abnormal trading volume in percentage points (see Equation 1) over a 7-trading-day window (days [-3 3]) centered around the CEO turnover announcement date (Day 0). Figure (a) refers to the total sample and Figure (b) to voluntary and forced turnovers. The dashed lines show the standard error of the standardized mean abnormal trading volumes.

(a) Total Sample

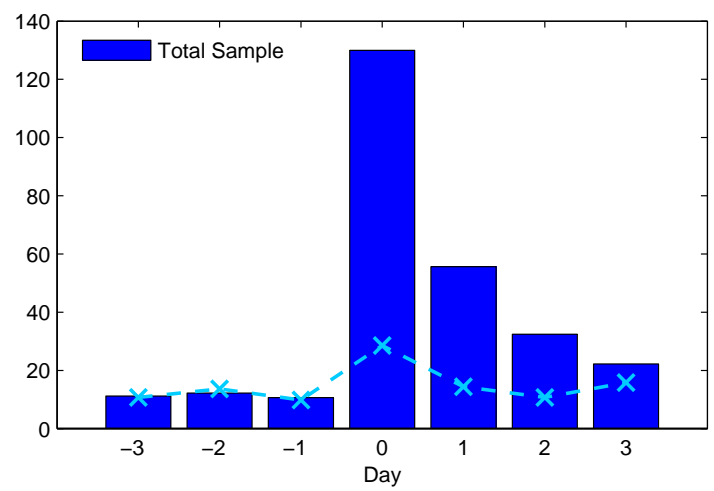

(b) Departure Type

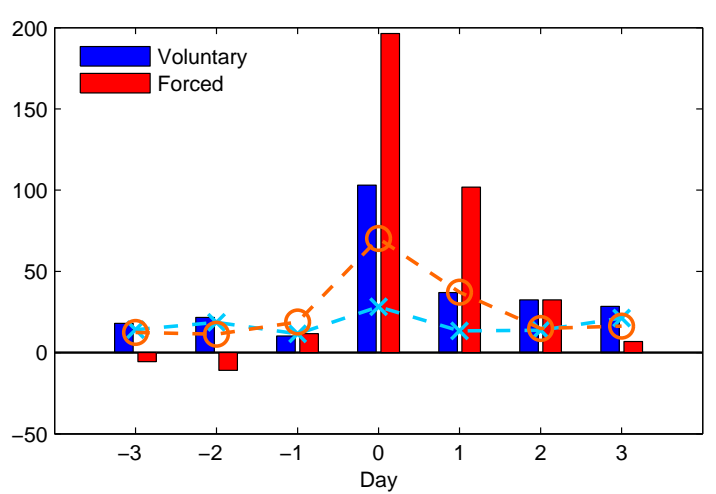


Figure 2: Cumulative Abnormal Returns

The following graphs show the average cumulative [-3 3]-ARs around the CEO turnover announcement date (Day 0). The cumulative ARs for the total sample are depicted in Figure (a). Figure (b) refers to the subsamples of voluntary and forced turnovers. Figure (c) refers to the subsamples of forced turnovers of high-quality (HQY) and low-quality (LQY) managers. The grey areas indicate $5 \%$ one-sided confidence intervals.

(a) Total Sample

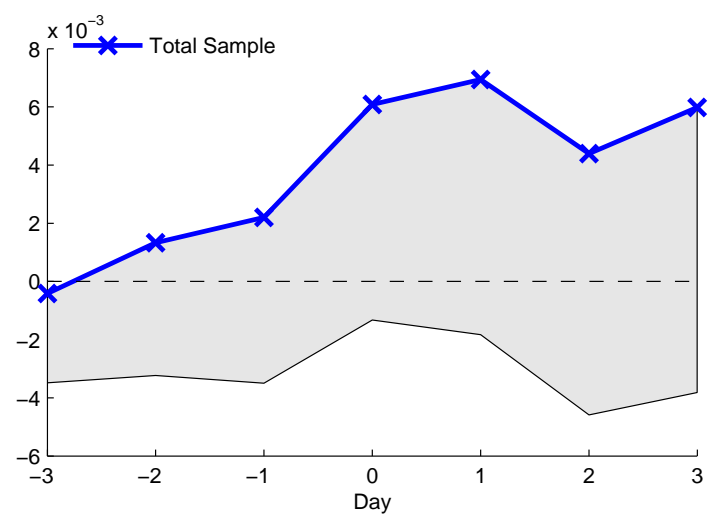

(b) Departure Type

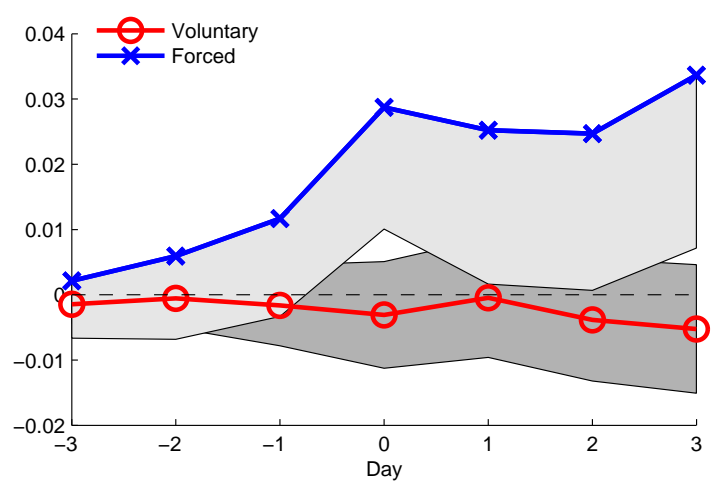

(c) Forced Departures and CEO Quality

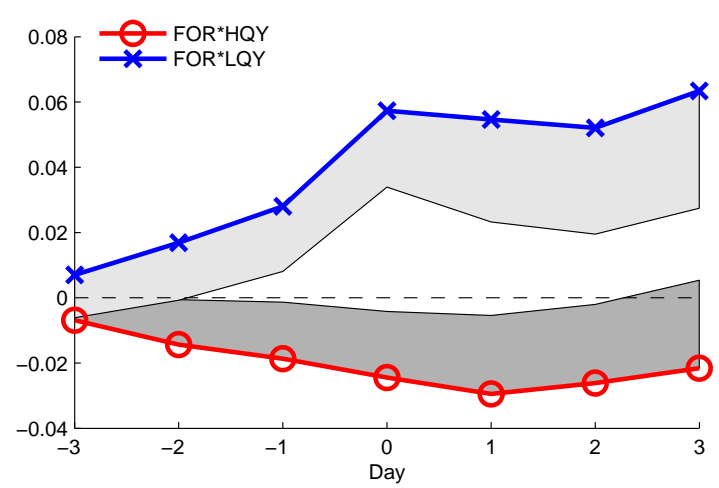


Figure 3: Changes in Operating Performance

The following graphs show the changes in the operating return on assets (OROA) in the years surrounding the CEO turnover. Figure (a) refers to the total sample. Figure (b) refers to the subsamples of voluntary and forced turnovers. Figure (c) refers to the subsamples of forced turnovers of high-quality (HQY) and low-quality (LQY) CEOs.

(a) Total Sample

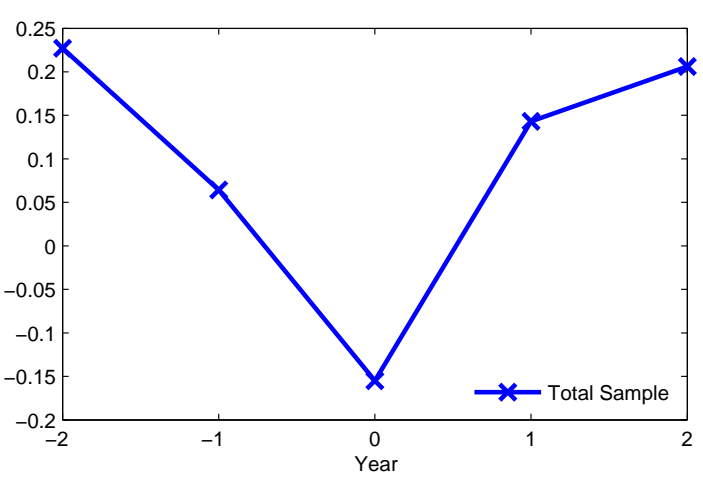

(b) Departure Type

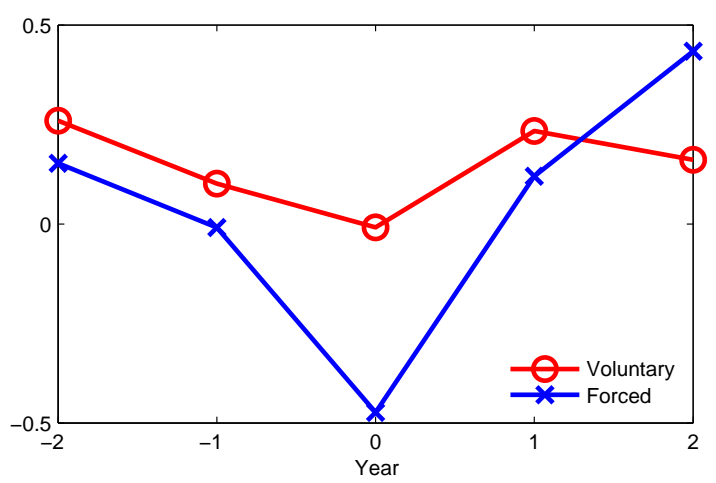

(c) Forced Departures and CEO Quality

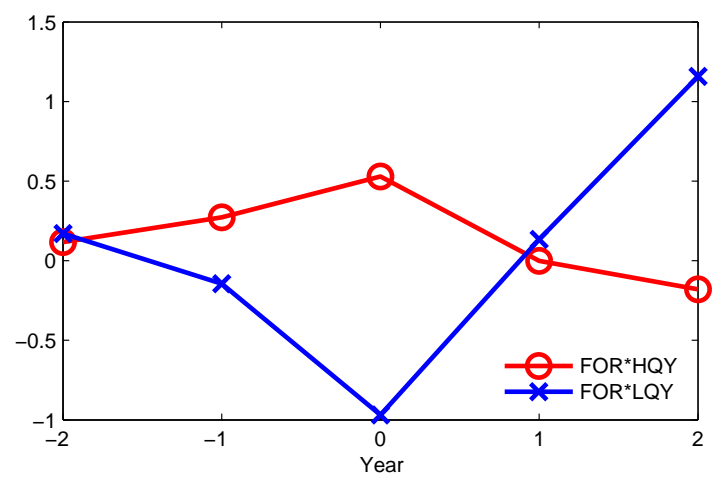

